\title{
HEINONLINE
}

Citation: 108 Colum. L. Rev. 13012008

Content downloaded/printed from

HeinOnline (http://heinonline.org)

Mon Jun 25 16:31:28 2012

-- Your use of this HeinOnline PDF indicates your acceptance of HeinOnline's Terms and Conditions of the license agreement available at http://heinonline.org/HOL/License

-- The search text of this PDF is generated from uncorrected OCR text.

-- To obtain permission to use this article beyond the scope of your HeinOnline license, please use:

https://www.copyright.com/ccc/basicSearch.do? \&operation $=$ go\&search Type $=0$

\&lastSearch $=$ simple\&all=on\&titleOrStdNo=0010-1958

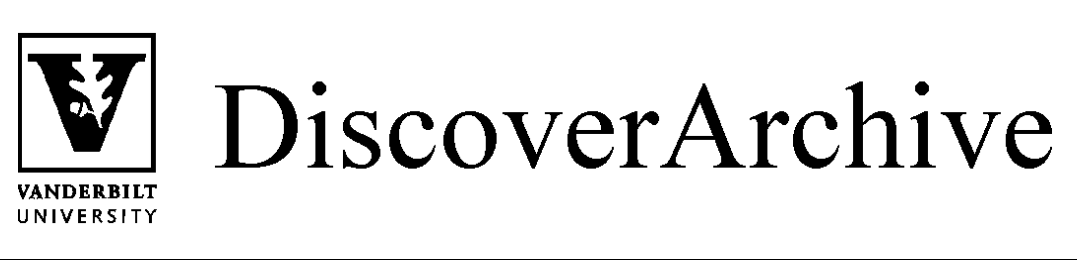

Retrieved from DiscoverArchive,

Vanderbilt University's Institutional Repository

This work was originally published in 108 Colum. L. Rev. 13012008. 


\title{
COLUMBIA LAW REVIEW
}

VOL. 108

ARTICLES

\section{REFORMING SECURITIES LITIGATION REFORM: RESTRUCTURING THE RELATIONSHIP BETWEEN PUBLIC AND PRIVATE ENFORCEMENT OF RULE 10B-5}

\author{
Amanda M. Rose*
}

Commentators have long debated how to reform the controversial Rule 10b-5 class action without pausing to ask whether the game is worth the candle. Is private enforcement of Rule 10b-5 worth preserving, or might we be better off with exclusive public enforcement? This fundamental but neglected question demands attention today more than ever. An academic consensus has emerged that the typical Rule 10b-5 class action cannot be defended on compensatory grounds. That leaves the oft-cited, but undertheorized, rationale that private enforcement is a "necessary supplement" to the securities fraud deterrence efforts of the SEC. When this justification is critically examined, however, it proves to be highly debatable. Law and economics scholarship teaches that "bounty hunter" enforcement of an overbroad law, like Rule 10b-5, may lead to overdeterrence and stymie govermmental efforts to set effective enforcement policy (even assuming away "strike suits" and the agency costs that attend class action litigation); if private enforcement is nevertheless desirable-a contestable proposition-it is because a world without it might result in even greater deviations from optimal deterrence, due to SEC budgetary constraints, inefficiency, and/or capture.

By carefully explicating the relative advantages and disadvantages of private Rule 10b-5 enforcement versus exclusive public enforcement, this Article reveals a new and better way to remedy the shortcomings of the Rule $10 b-5$ class action. It proposes that policymakers adopt an "oversight approach" to securities litigation reform by, for example, granting the SEC the ability to screen which Rule $10 b-5$ class actions may be filed, and against whom. By muting the overdeterrence threat of private litigation and placing the SEC back at the helm of Rule 10b-5 enforcement policy, this approach would mitigate the primary disadvantages of private enforcement. Moreover, by preserving a private check on SEC inefficiency and regulatory capture, and allowing the SEC to continue to supplement its budget with private enforcement resources, it would do so without eliminating the primary ad-

* Assistant Professor of Law, Vanderbilt University Law School. I am very grateful for the support I received in connection with this project. I owe a special debt of gratitude to Mark Perry and Eric Talley; I would also like to thank the many others who read and commented on prior drafts, including Joshua Benson, Richard Buxbaum, John Coffee, Richard Nagareda, Hal Scott, Fred Tung, and attendees at presentations given at various law schools over the course of the past year. All mistakes are, of course, my own. 
vantages of the current system. This approach stands in contrast to prior securities litigation reforms, which have responded to the overdeterrence threat posed by Rule 10b-5 class actions by rigidly narrowing the scope of private liability.

INTRODUCTION ................................. 1302

I. A Brief History of the Rule 10b-5 Class Action....... 1307

A. From Kardon to Borak: The Shifting Raison D'Etre of Private Enforcement ...................... 1310

B. The Private Attorney General Falls into Disrepute .... 1315

C. The Private Securities Litigation Reform Act of 1995 . 1318

D. The Status Quo ......................... 1321

II. Is Private Enforcement Really a "Necessary

SupPlement" to Commission Action? .............. 1325

A. The Shortcomings of Bounty Enforcement ........ 1326

1. The Instability Problem .................. 1326

2. The Inflexibility Problem ................ 1328

B. The Relative Effectiveness of Public Versus Private

Enforcement of Rule 10b-5 .................. 1330

1. Is Overdeterrence a Risk? ................. 1331

2. Are Private Enforcers Profit Driven? .......... 1337

3. Are Public Enforcers Better Able to Represent the Public Interest? ......................... 1340

4. Do Special Factors Weigh in Favor of Private Enforcement? ........................... 1343

III. Improving Deterrence by Restructuring the

Relationship Between Commission and Private

ENFORCEMENT .............................. 1349

A. The Narrowing Approach $\ldots \ldots \ldots \ldots \ldots \ldots \ldots \ldots, 1353$

B. The Oversight Approach .................. 1354

C. Potential Challenges to an Oversight Regime ....... 1358

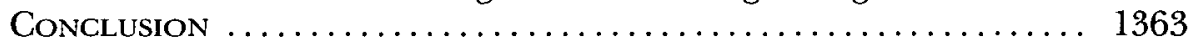

\section{INTRODUCTION}

The overwhelming majority of securities fraud class actions are brought under Section 10(b) of the Securities Exchange Act of 1934 and its implementing regulation, Rule $10 \mathrm{~b}-5 .{ }^{1}$ Most commentators now agree

1. Section 10 (b) provides that:

It shall be unlawful for any person, directly or indirectly . . . [t]o use or employ, in connection with the purchase or sale of any security ... any manipulative or deceptive device or contrivance in contravention of such rules and regulations as the Commission may prescribe as necessary or appropriate in the public interest or for the protection of investors.

15 U.S.C. $\$ 78 \mathrm{j}$ (2006). In Rule 10b-5, the Commission declared:

It shall be unlawful for any person, directly or indirectly . . . (a) To employ any device, scheme, or artifice to defraud, (b) To make any untrue statement of a material fact or to omit to state a material fact necessary in order to make the statements made, in the light of the circumstances under which they were made, 
that the private right of action implied under Section 10(b)-famously called a "judicial oak which has grown from little more than a legislative acorn"2-cannot be defended on compensatory grounds, at least in its most common form: the fraud-on-the-market class action brought against a nontrading issuer. It has been severed, to continue the late Chief Justice's metaphor, from the private law roots from which it sprang, and today finds defense, if at all, on deterrence grounds. Yet when it comes to deterrence, most observers also agree that Rule $10 \mathrm{~b}-5$ class actions perform poorly.

Beyond that, the consensus breaks down. Some proclaim that the specter of Rule 10b- 5 class actions, and the massive liability they threaten, has led to overdeterrence-even to the extent of driving issuers away from the U.S. capital markets altogether, thus placing the United States at a competitive disadvantage relative to foreign markets. In the much anticipated Supreme Court decision in Stoneridge Investment Partners, LLC v. Scientific-Atlanta, Inc., for example, a five-Justice majority recently warned that the Rule 10b-5 class action "may raise the cost of being a publicly traded company under our law and shift securities offerings away from domestic capital markets." 3 Others, by contrast, charge that restrictions on the implied right imposed by the Private Securities Litigation Reform Act of 1995 (PSLRA) ${ }^{4}$ and decisions such as Central Bank of Denver, N.A. $v$. First Interstate Bank of Denver, N.A., ${ }^{5}$ reaffirmed in Stoneridge, have led to underdeterrence, contributing to a climate of corporate permissiveness that led to scandals like Enron and Worldcom. Indeed, the Stoneridge dissent, authored by Justice Stevens, bemoaned "the Court's continuing campaign to render the private cause of action under [Rule 10b-5] toothless." 6 Still others recognize that Rule 10b-5 class actions may both overdeter some actors (e.g., issuers, who face essentially strict enterprise liability for the frauds of their agents) and underdeter others (e.g., individual wrongdoers, who are rarely forced to contribute to settlements, and "gatekeepers"-like auditors and investment banks-who may escape liability under the rule of Central Bank). ${ }^{7}$

Various reform proposals designed to remedy the perceived deterrent shortcomings of the Rule $10 \mathrm{~b}-5$ class action have been offered in

not misleading, or (c) To engage in any act, practice, or course of business which operates or would operate as a fraud or deceit upon any person, in connection with the purchase or sale of any security.

17 C.F.R. $\S 240.10$ b-5 (2008).

2. Blue Chip Stamps v. Manor Drug Stores, 421 U.S. 723, 737 (1975).

3. 128 S. Ct. 761,772 (2008).

4. Pub. L. No. 10467, 109 Stat. 737 (codified as amended in scattered sections of 15 U.S.C. and 18 U.S.C.).

5. 511 U.S. 164, 191 (1994) (holding private plaintiff may not maintain aiding and abetting suit under $\S 10(\mathrm{~b})$ ).

6. $128 \mathrm{~S}$. Ct. at 779 (Stevens, J., dissenting).

7. See John C. Coffee, Jr., Law and the Market: The Impact of Enforcement, $156 \mathrm{U}$. Penn. L. Rev. 229, 305 (2007) [hereinafter Coffee, Law and the Market]. 
recent years. These proposals, while diverse in their prescriptions, share a common theme: All proceed from the assumption that private Rule $10 \mathrm{~b}-5$ enforcement is a "necessary supplement" ${ }^{2}$ to the Rule 10b-5 enforcement efforts of the Securities and Exchange Commission. That assumption, however, is not self-evidently correct. To the contrary, once the notion that Rule $10 \mathrm{~b}-5$ class actions serve a meaningful compensatory function is cast aside, permitting "private attorneys general" to prosecute securities fraud cases reveals itself as a rather debatable proposition.

Law and economics scholarship teaches that it is especially difficult to achieve optimal deterrence when private parties are granted the right to enforce overbroad liability rules for financial reward. "Bounty hunter" actions may lead to overenforcement and, as a result, overdeterrence. ${ }^{9}$ They may also make for a relatively inflexible enforcement system. A monopolistic public enforcer can deal with the overdeterrent potential of an overbroad liability rule through use of discretionary nonenforcement, or by pursuing a cooperative approach to regulation, and it can adjust its approach if it appears to have gotten the deterrence calculus wrong (which will often be the case, in light of imperfect and changing information). Private enforcement, however, nullifies the public enforcer's ability to effectively utilize these tools by ensuring that the law will be enforced to its outermost limits, regardless of the public enforcer's desires, so long as such enforcement is profitable. ${ }^{10}$ Monopolistic public enforcement carries its own risks, of course. Its relative superiority as a means of achieving (or, more realistically, approximating) optimal deterrence will depend on several key factors specific to the particular law at issue and the character of the would-be enforcers.

When these teachings are applied in the specific context of Rule $10 \mathrm{~b}-5$ enforcement, an interesting-though incomplete-picture emerges. As written, Rule $10 \mathrm{~b}-5$ is clearly overbroad, particularly when enterprise liability and hazy concepts such as materiality are considered. If Rule $10 \mathrm{~b}-5$ were enforced to its outermost limits, then, it would induce socially undesirable conduct, like an issuer's excessive investment in precautions to protect against fraud by its agents (conduct that, like securities fraud itself, increases the cost of capital to no good end). Moreover, the plaintiffs' securities bar is enticed to bring suit by the prospect of financial reward-an intuitive observation that is bolstered by evidence showing a correlation between an issuer's market capitalization (which is related to the size of the potential damage award and, in turn, the potential contingency fee) and the likelihood of being sued in a Rule 10b-5 class action. ${ }^{11}$ These two facts make it predictable that unrestricted private enforcement of Rule 10b-5 would, at least as it concerns companies with large market capitalizations, lead to overenforcement and frustrate

8. J. I. Case Co. v. Borak, 377 U.S. 426, 432 (1964).

9. See infra notes $116-127$ and accompanying text.

10. See infra notes $128-135$ and accompanying text.

11. See infra notes $161-163$ and accompanying text. 
the Commission's ability to set, and adjust, Rule 10b-5 enforcement policy.

These facts do not reveal, however, whether exclusive Commission enforcement would move us closer to optimal deterrence than the status quo. That leap requires one to accept the proposition that the interests of the Commission are better aligned with the public's interest in achieving optimal deterrence than are the interests of the plaintiffs' securities bar. Concerns about bureaucratic inefficiency and regulatory capture may lead some to predict that exclusive Commission enforcement would result in greater deviations from optimal deterrence than would private enforcement. So, too, may concerns about the Commission's actual or potential budgetary constraints. Thus, it is not clear whether private Rule $10 \mathrm{~b}-5$ enforcement is desirable, or undesirable, relative to a system of exclusive Commission enforcement. Nor is the question readily subject to empirical testing.

Although it is unclear how they balance out, identifying the relative advantages and disadvantages of private Rule $10 \mathrm{~b}-5$ enforcement versus exclusive Commission enforcement is an important exercise. It allows one to conceptualize the deterrence shortcomings of the Rule 10b-5 class action in a different way, and suggests a means of remedying those shortcomings that is superior to alternatives heretofore proposed. For the past twenty-five years, the securities litigation reform debate has centered on how to reduce the agency costs borne of the attorney-client relationship; ${ }^{12}$ more recently, substantial criticism has been heaped on the out-ofpocket measure of damages used in Rule $10 \mathrm{~b}-5$ class actions. ${ }^{13}$ But even if these agency costs were eliminated entirely (i.e., even if the interests of class members and their counsel were perfectly aligned), and even if the out-of-pocket measure of damages utilized in Rule $10 \mathrm{~b}-5$ class actions were reformed, the risk that private enforcement of Rule $10 \mathrm{~b}-5$ would lead to socially undesirable overdeterrence would remain. Such is the natural consequence of-and fundamental problem with-permitting profit-driven private enforcement of an overbroad law. ${ }^{14}$

Short of eliminating private enforcement altogether, there are two very different ways that policymakers can approach this problem. First, they can narrow the scope of the private right-either directly, by altering the substantive liability rule, or indirectly, by altering the procedural law to disfavor the particular types of suits thought most undesirable (the "narrowing approach"). Second, they can grant the public enforcer some level of control over private litigation, so as to reintroduce the possibility

12. See infra notes $67-76$ and accompanying text.

13. See infra notes $98-100$ and accompanying text.

14. See infra Part II.A. Of course, if the damages measure were reformed in such a way as to render Rule $10 \mathrm{~b}-5$ class actions unprofitable to pursue, private enforcement would no longer present a risk of overdeterrence. This would be akin to eliminating private enforcement altogether. 
of discretionary nonenforcement and cooperative regulation (the "oversight approach").

The narrowing approach has been the mainstay of securities litigation reform efforts to date. Aspects of the PSLRA, key judicial decisions like Central Bank, and contemporary proposals to eliminate private enterprise liability can all be viewed as seeking to narrow Rule 10b-5's overbreadth in an effort to mitigate the overdeterrence threatened by private enforcement. ${ }^{15}$ It is a costly approach-the flip side of an overbroad Rule $10 \mathrm{~b}-5$ is an underinclusive one. To the extent that the Commission is unable (or unwilling) to pick up the enforcement slack, narrowing the private right of action serves to replace the risk of overdeterrence with the risk of underdeterrence.

The oversight approach avoids this conundrum, but has been given very little attention as a potential mechanism for reform. If the Commission were authorized to prescreen all Rule $10 \mathrm{~b}-5$ class action complaints, for example, and decide which may be filed, there would be less need to rigidly narrow the implied right. Instead, we might rely on the Commission's exercise of its expert discretion to protect against overdeterrence. Such a system could have the added benefit of enabling the Commission to flexibly alter its enforcement strategies when new information or changed circumstances suggest that doing so would lead closer to optimal deterrence.

If structured properly, a reform proposal grounded in increased Commission oversight of private Rule $10 \mathrm{~b}-5$ litigation has much to recommend it. Not only could it eliminate the core problem with Rule $10 \mathrm{~b}-5$ class actions without the tradeoffs required by the narrowing approach, but it could potentially do so without undermining the only two plausible bases for supplementing the Commission's deterrence efforts with private enforcement-namely, the desire to harness additional enforcement resources, and the fear that if the Commission were left to its own devices, laxity or capture would mar its Rule $10 \mathrm{~b}-5$ enforcement efforts. With respect to the former, the prospect of recovery if the right to file is granted, combined with a right to reasonable recompense if the Commission chooses to take over the matter, might provide adequate incentives for private enforcers to investigate wrongdoing and otherwise participate in the system, thus ensuring, in conjunction with the Commission's own efforts, a steady level of enforcement activity. With respect to the latter, requirements that the Commission promulgate principles guiding its decision whether to grant or deny the right to file, state in writing the reasons for its decision in a particular case, and report to Congress periodically on its track record of decisions might serve as an antidote.

The intent of this Article is not to advocate a specific reform package, but rather to demonstrate that increased SEC oversight of private Rule $10 \mathrm{~b}-5$ litigation is a conceptual approach to reform deserving of fur-

15. See infra notes $151-155$ and accompanying text. 
ther study and exploration. Although Commission oversight of Rule $10 \mathrm{~b}-5$ class actions has not received attention in the securities litigation reform debate, government oversight is actually the norm in those rare cases where Congress has expressly granted private parties the right to sue to enforce the public interest absent a corresponding tort-like injury that can be meaningfully redressed through litigation. ${ }^{16}$ The False Claims Act, for example, authorizes the Department of Justice to intervene and to move to dismiss a qui tam action brought under that statute, regardless of whether the suit has merit, and notwithstanding that the government itself has not pursued relief against the defendant; where the government has pursued relief, private enforcement is categorically barred. ${ }^{17}$ The fact that no comparable restrictions attend Rule $10 \mathrm{~b}-5$ class actions is a vestige of the implied right's compensatory origins, which, as noted at the outset, no longer serve to justify private Rule $10 \mathrm{~b}-5$ enforcement via the class device. Policymakers should not allow the outdated form of private Rule 10b-5 litigation to dictate the substance of possible reforms any longer.

Part I of this Article traces the evolution of the private right of action under Rule $10 \mathrm{~b}-5$ from its compensatory beginnings to the present day, explaining that the modern Rule $10 \mathrm{~b}-5$ class action is justifiable, if at all, on deterrence grounds. Part II questions whether the Rule $10 \mathrm{~b}-5$ class action is truly a "necessary supplement" to the Commission's deterrence efforts, applying law and economics scholarship to evaluate the relative advantages and disadvantages of private Rule $10 \mathrm{~b}-5$ enforcement versus exclusive Commission enforcement. Part III then explains how enhanced Commission oversight of private Rule $10 \mathrm{~b}-5$ actions might minimize the disadvantages and maximize the advantages of both regimes, and answers some potential objections to the reforms proposed. The Article then briefly concludes.

\section{A Brief History Of The Rule 10b-5 Class Action}

The story of private Rule $10 \mathrm{~b}-5$ enforcement begins with the advent of federal securities regulation itself. In the wake of the stock market crash of 1929 and the ensuing Great Depression, Congress enacted the Securities Exchange Act of 1934 as one in a series of statutes designed to promote "a philosophy of full disclosure" 18 in the national securities markets. In section 4 of the Act, Congress created the Securities and Exchange Commission as the expert agency with responsibility for the

16. See, e.g., 31 U.S.C. $\$ 3730$ (2000) (detailing oversight provisions of False Claims Act); 33 U.S.C. $\$ 1365$ (2000) (same for Clean Water Act); 42 U.S.C. $\$ 7604$ (2000) (same for Clean Air Act).

17. See infra notes 221-224 and accompanying text.

18. SEC v. Capital Gains Research Bureau, Inc., 375 U.S. 180, 186-87 (1963). 
civil enforcement of these new statutes, ${ }^{19}$ and in section 10(b) Congress granted the Commission broad authority to enact regulations banning manipulation or deception in connection with the purchase or sale of securities. ${ }^{20}$

The Commission exercised the fullest extent of its delegated authority under section $10(\mathrm{~b})$ in 1942, when it enacted Rule 10b-5. ${ }^{21}$ The purpose of the Rule was to close a loophole in the Commission's enforcement authority by prohibiting individuals or companies from buying securities if they engaged in fraud in their purchase; previously enacted rules prohibited only the fraudulent sale of securities (or applied only to brokers and dealers). ${ }^{22}$ The Rule's primary drafter "never thought that twenty-odd years later it would be the biggest thing that had ever happened" in the securities realm. ${ }^{23}$

Although Rule 10b-5 "had no relation in the Commission's contemplation to private proceedings" 24 -and even less in Congress' ${ }^{25}$ _just five years after its promulgation the United States District Court for the Eastern District of Pennsylvania found an implied private right of action to sue for damages under the Rule in Kardon v. National Gypsum Co. ${ }^{26}$ The court did so despite the existence of several expressly enumerated private causes of action elsewhere in the 1934 Act and the Securities Act of $1933,{ }^{27}$ the very presence of which might have been read to suggest a congressional intent not to provide additional private remedies. ${ }^{28}$ The

19. See Pub. L. No. 73-291, $\S 4,48$ Stat. 881,885 (codified as amended at 15 U.S.C. $\S 78 \mathrm{~d}(2006))$. For a historical account, see Joel Seligman, The Transformation of Wall Street 99-100 (3d ed. 2003).

20. See Pub. L. No. 73-291, $\$ 10(\mathrm{~b})$, 48 Stat. at 891 (codified as amended at 15 U.S.C. $\S 78 \mathrm{j}(\mathrm{b})$ ); see also Ernst \& Ernst v. Hochfelder, 425 U.S. 185, 203 (1976) ("The section was described rightly [by a spokesman for its drafters] as a 'catchall' clause to enable the Commission 'to deal with new manipulative [or cunning] devices." (citation omitted)).

21. See Exchange Act Release No. 3230, 7 Fed. Reg. 3804, 3804 (May 21, 1942); 17 C.F.R. 240.10b-5 (2008).

22. See Exchange Act Release No. 3230, 7 Fed. Reg. at 3804; Birnbaum v. Newport Steel Corp., 193 F.2d 461, 463 (2d Cir. 1952).

23. Milton Freeman, Remarks at Conference on Codification of the Federal Securities Laws (Nov. 18, 1966), in 22 Bus. Law. 793, 922 (1967). "In 2005, 93 percent of securities class actions alleged violations of Rule 10b-5." Tom Baker \& Sean J. Griffith, Predicting Corporate Governance Risk: Evidence from the Directors' \& Officers' Liability Insurance Market, 74 U. Chi. L. Rev. 487, 498 (2007); see also Steve Thel, The Original Conception of Section 10(b) of the Securities Exchange Act, 42 Stan. L. Rev. 385, 463 (1990) (noting that Rule 10b-5 "has been given extraordinary prominence, almost eclipsing everything else as a source of federal securities law at least in the courts").

24. Freeman, supra note 23, at 922.

25. See Blue Chip Stamps v. Manor Drug Stores, 421 U.S. 723, 729 (1975) ("[T]he history of this provision [does not] provide any indication that Congress considered the problem of private suits under it at the time of its passage.").

26. 69 F. Supp. 512, 513-14 (E.D. Pa. 1946).

27. Id. at 514; see also Pamela H. Bucy, Private Justice, 76 S. Cal. L. Rev. 1, 23-25 (2002) (cataloguing express private rights of action in the 1933 and 1934 Acts).

28. Implied private rights of action have been denied under other sections of the securities laws due in part to the existence of these express private remedies. See, e.g., 
Kardon holding was adopted by "an overwhelming consensus of the District Courts and Courts of Appeals," ${ }^{29}$ and by the Supreme Court a quarter century later in Superintendent of Insurance $v$. Bankers Life $\mathcal{E}^{\circ}$ Casualty $\mathrm{Co}^{30}$ Although Kardon would not be decided the same way today, 31 "the existence of a private cause of action for violations of the statute and the Rule is now well established" and has been repeatedly reaffirmed. ${ }^{32}$

While the courts have not wavered in their recognition of the private right to sue for damages under Rule $10 \mathrm{~b}-5$, the justification for its existence has undergone significant transformation since 1946. Part I.A explains that the right was originally implied to serve a compensatory function, but that the modern Rule 10b-5 class action that emerged in the late 1960s provides little if any meaningful compensation to investors, and instead finds its primary justification in its potential deterrent effect. Modern private enforcement via the class device therefore serves the same purpose as the Commission's enforcement of Rule 10b-5. The wisdom of allowing "private attorneys general" to enforce Rule $10 \mathrm{~b}-5$ in this manner is not self-evident, but has been subject to surprisingly little challenge. Part I.B explains why, describing how scholarship focused on the agency costs borne of the attorney-client relationship came to dominate the class action reform debate beginning in the 1980s, eclipsing more

Touche Ross \& Co. v. Redington, 442 U.S. 560, 571-72 (1979) (finding no private right of action for damages under $\$ 17(\mathrm{a})$ of the Exchange Act, and explaining that "when Congress wished to provide a private damages remedy, it knew how to do so and did so expressly").

29. Merrill Lynch, Pierce, Fenner \& Smith, Inc. v. Dabit, 547 U.S. 71, 79 (2006) (internal quotation marks omitted).

30. 404 U.S. 6,13 n.9 (1971).

31. Since Justice Powell's dissent in Cannon v. University of Chicago, 441 U.S. 677, $730-49$ (1979), the Court generally has been reluctant to find implied private rights of action in federal statutes. See Alexander v. Sandoval, 532 U.S. 275, 286-88 (2001) (discussing evolution of Court's jurisprudence, disfavoring implied private rights of action); Joseph A. Grundfest, Disimplying Private Rights of Action Under the Federal Securities Laws: The Commission's Authority, 107 Harv. L. Rev. 963, 992-94 (1994) [hereinafter Grundfest, Rights of Action] (describing implied private right of action under section 10 (b) and Rule 10b-5 as having been "grandfathered" by the Court, but noting that Court's current analytical framework no longer supports finding such a right); Mark A. Perry, Stoneridge and the Continued Reconceptualization of Implied Private Rights of Action, Wall St. Law., Feb. 2008, at 1, 6-7 (noting refusal of Court in Stoneridge to extend scope of private right beyond that explicitly ratified by Congress in enacting the PSLRA).

32. Ernst \& Ernst v. Hochfelder, 425 U.S. 185, 196 (1976); see also Herman \& Maclean v. Huddleston, 459 U.S. 375, 380 (1983) ("The existence of this implied remedy is simply beyond peradventure."). Indeed, Congress has enacted two significant pieces of legislation-the Private Securities Litigation Reform Act of 1995 (PSLRA), Pub. L. No. 104 67, Sec. $101(\mathrm{a})-(\mathrm{b}), \S \S 21 \mathrm{D}, 27,109$ Stat. 737, 737, 743 (codified as amended at 15 U.S.C. $\$ \$ 77 z-1,78 u-4$ (2006)), and the Securities Litigation Uniform Standards Act of 1998 (SLUSA), Pub. L. No. 105-353, Sec. 101(a) (2), 101(b) (2), § 21D, 27, 112 Stat. 3227, 3230, 3233 (codified at 15 U.S.C. $\$ \S 77 \mathrm{z}-1,78 \mathrm{u}-4$ ) - that acknowledge the existence of the right. See also Tellabs, Inc. v. Makor Issues \& Rights, Ltd., 127 S. Ct. 2499, 2507-10 (2007) (interpreting the PSLRA). 
fundamental challenges to private enforcement of Rule 10b-5. Part I.C situates the Private Securities Litigation Reform Act of 1995 (PSLRA) in this historical context. Part I.D describes the problems that continue, even after the PSLRA, to frustrate the ability of Rule $10 \mathrm{~b}-5$ class actions to ensure optimal deterrence, and contemporary reform proposals designed to mitigate these lingering problems. Notably, these proposals continue to perpetuate the assumption that private enforcement is desirable. This Article tests that assumption in Part II.

\section{A. From Kardon to Borak: The Shifting Raison D'Être of Private Enforcement}

When originally recognized by the courts, the implied private right of action under Rule 10b-5 served a purpose distinct from the purpose served by Commission enforcement of the rule. Commission enforcement operated primarily to deter securities fraud in order to promote society's collective interest in the integrity and efficiency of the capital markets; private enforcement, by contrast, operated primarily to compensate defrauded investors for their discrete losses-much like a common law claim for misrepresentation and deceit. Kardon was premised on the view that " $[t]$ he disregard of the command of a statute is a wrongful act and a tort," entitling the injured party to compensation. ${ }^{33}$ This private law paradigm premised on corrective justice ideals fit the facts of Kardon quite well: The defendants had personally duped the plaintiffs into selling them stock at less than its true value, and forcing the defendants to compensate the plaintiffs for their injuries would set right this wrong. Indeed, in Kardon itself the plaintiffs could have proceeded under either Rule $10 \mathrm{~b}-5$ or the common law; the real issue was whether they could take advantage of the 1934 Act's provision for nationwide service of process. ${ }^{34}$

To be sure, there was overlap between SEC and private Rule $10 \mathrm{~b}-5$ enforcement even in the early days: The Commission would sometimes return disgorged funds to investors, and the threat of a private lawsuit might operate, incidentally, to deter. But public and private Rule $10 \mathrm{~b}-5$ enforcement occupied analytically distinct spheres. This distinction is reflected in the divergent remedies available in private Rule $10 \mathrm{~b}-5$ actions and Commission enforcement actions. Private actions permit only a singular tort remedy: the recovery of compensatory damages, most often calculated using an out-of-pocket measure. ${ }^{35}$ Commission actions, by contrast, permit a panoply of remedies, enabling the Commission to per-

33. 69 F. Supp. 512, 513 (E.D. Pa. 1946). The Supreme Court has since repudiated this approach to the implication of private rights of action under federal statutes. See supra note 31 .

34. 69 F. Supp. at 514.

35. Robert F. Serio, Mark Holton \& Aric H. W'u, Basic Claims Under the Federal Securities Laws, in Securities Litigation: A Practitioner's Guide $\$ \S 2: 1,2: 2.2$ [A][4] (Jonathan C. Dickey ed., 2006). 
form its deterrent function in a finely calibrated manner, depending on the facts and circumstances of the particular case before it. ${ }^{36}$

Beginning in the 1960s, the distinction between public and private Rule $10 \mathrm{~b}-5$ enforcement began to blur. The emergence of the modern class action device in $1966,{ }^{37}$ made widely applicable in securities cases by the fraud-on-the-market presumption of reliance, catalyzed the change. ${ }^{38}$ In common law fraud cases, plaintiffs must prove that they actually read and relied upon the allegedly misleading disclosures, raising individualized issues that render class certification difficult. ${ }^{39}$ The fraud-on-themarket presumption of reliance available in Rule $10 \mathrm{~b}-5$ cases obviates that requirement, so long as the plaintiffs purchased their shares in an efficient market. ${ }^{40}$ It therefore "invites class certification (and a subsequent

36. These remedies, the availability of which vary somewhat depending on whether the Commission initiates an administrative proceeding or files suit directly in federal court, today include civil money penalties, tiered in amount depending on the egregiousness of the violation; officer and director bars; injunctive relief; cease and desist orders; disgorgement of ill-gotten gains; and orders requiring corrective disclosures and corporate governance changes, among other things. See Vincent J. Badolato, Dennis J. Lawson \& Carolyn M. Welshhans, SEC Proceedings-An Overview, in Securities Law Techniques $\$ \S 87,87.06-87.07$ (A.A. Sommer, Jr. ed., 2006); James D. Cox \& Randall S. Thomas, SEC Enforcement Heuristics: An Empirical Inquiry, 53 Duke L.J. 737, 746-48 (2003) [hereinafter Cox \& Thomas, SEC Enforcement Heuristics] (describing SEC enforcement mechanisms); John H. Sturc \& Jonathan C. Dickey, SEC Investigations and Enforcement Actions, in Securities Litigation: A Practitioner's Guide, supra note 35, §§ 15:3.2-15:3.3; see also Securities Enforcement Remedies and Penny Stock Reform Act of 1990, Pub. L. No. 101-429, 104 Stat. 931 (codified as amended in scattered sections of 15 U.S.C.) (amending securities laws to provide additional enforcement remedies). In addition, a Commission investigation may lead to a negotiated resolution prior to formal charges being filed against the defendant. Kenneth B. Winer, Samuel J. Winer \& Gregory S. Bruch, Settlement Discussions, in 1 Securities Enforcement: Counseling and Defense $\$ \S 17$, 17.03[2] (Kenneth B. Winer \& Samuel J. Winer eds., 2007). The Commission may also refer violations to the Department of Justice for criminal prosecution. Sturc \& Dickey, supra, $\$ 15: 3.4$.

37. See Fed. R. Civ. P. 23 advisory committee's notes to 1966 amendments (discussing changes in class action rule).

38. See Basic Inc. v. Levinson, 485 U.S. 224, 241-47 (1988) (adopting the presumption); Paul G. Mahoney, Precaution Costs and the Law of Fraud in Impersonal Markets, 78 Va. L. Rev. 623, 663 (1992) (reporting that "the rate at which securities fraud class action suits were filed nearly tripled between April 1988, just after Basic was decided, and June 1991").

39. See Amanda M. Rose, Life After SLUSA: What Is the Fate of Holding Claims?, 69 Def. Couns. J. 455, 464 (2002).

40. Daniel R. Fischel, Use of Modern Finance Theory in Securities Fraud Cases Involving Actively Traded Securities, 38 Bus. Law. 1, 9-10 (1982) [hereinafter Fischel, Modern Finance Theory]; Donald C. Langevoort, Capping Damages for Open-Market Securities Fraud, 38 Ariz. L. Rev. 639, 645 \& n.31 (1996) [hereinafter Langevoort, Capping Damages]. As the Supreme Court has explained:

The fraud on the market theory is based on the hypothesis that, in an open and developed securities market, the price of a company's stock is determined by the available material information regarding the company and its business .... Misleading statements will therefore defraud purchasers of stock even if the purchasers do not directly rely on the misstatements .... The causal connection 
trial on the merits) by moving this one issue on which there will be substantial variation among the plaintiffs to a later stage of the proceeding, and then only if the defendant wishes to assume the burden of negating it." 11

By vastly expanding the number of plaintiffs who may presumptively recover, and allowing them to pursue relief collectively via the class device, the fraud-on-the-market presumption dramatically raised the stakes of Rule 10b-5 litigation. ${ }^{42}$ Not surprisingly, the prototypical Rule $10 \mathrm{~b}-5$ case became a class action brought on behalf of thousands of investors, based on misstatements or omissions made in public disclosure documents that most class members never read, against a deep-pocketed corporate defendant that did not itself profit from the fraud. ${ }^{43}$ This type of case is "light years away" from the common law tort of misrepresentation and deceit. ${ }^{44}$

Most notably for purposes of this Article, Rule 10b-5 class actions fail to provide meaningful compensation to the class members on whose be-

between the defendants' fraud and the plaintiffs' purchase of stock in such a case

is no less significant than in a case of direct reliance on misrepresentations.

Basic, 485 U.S. at 241-42 (citation omitted).

41. Donald C. Langevoort, Theories, Assumptions, and Securities Regulation: Market Efficiency Revisited, 140 U. Pa. L. Rev. 851, 892 (1992). For further discussion of the implications of the fraud-on-the-market presumption for class certification, see Jennifer Arlen \& William J. Carney, Vicarious Liability for Fraud on Securities Markets: Theory and Evidence, 1992 U. Ill. L. Rev. 691, 696-98 [hereinafter Arlen \& Carney, Vicarious Liability]; A.C. Pritchard, Markets As Monitors: A Proposal to Replace Securities Class Actions with Exchanges as Securities Fraud Enforcers, 85 Va. L. Rev. 925, 948 (1999) [hereinafter Pritchard, Markets as Monitors]. The Fifth Circuit recently issued a decision that could make it more difficult to achieve class certification in securities cases. See Oscar Private Equity Invs. v. Allegiance Telecom, Inc., 487 F.3d 261, 264-70 (5th Cir. 2007) (requiring plaintiffs at class certification stage to establish loss causation by preponderance of the evidence in order to trigger fraud-on-the-market presumption of reliance).

42. "Given the volume of trading in secondary trading markets, the damages recoverable in such suits can be a substantial percentage of the corporation's total capitalization, reaching the tens or even hundreds of millions of dollars." Pritchard, Markets as Monitors, supra note 41, at 928 .

43. "Courts have largely assumed that when an executive speaks or acts fraudulently within the scope of his or her authority and in a manner at least partially meant to benefit the corporation, the corporation is jointly and severally liable." Donald C. Langevoort, On Leaving Corporate Executives "Naked, Homeless and Without Wheels": Corporate Fraud, Equitable Remedies, and the Debate over Entity Versus Individual Liability, 42 Wake Forest L. Rev. 627, 631 (2007) [hereinafter Langevoort, Leaving Executives Naked]. While insiders are regularly named as codefendants, they rarely contribute to the settlement. John C. Coffee, Jr., Reforming the Securities Class Action: An Essay on Deterrence and Its Implementation, 106 Colum. L. Rev. 1534, 1550 (2006) [hereinafter Coffee, Reforming Securities Class Action]. Instead, the vicariously liable corporate defendant almost always foots the bill. See Arlen \& Carney, Vicarious Liability, supra note 41, at 695-96 (discussing enterprise liability in securities cases); A.C. Pritchard, Who Cares?, 80 Wash. U. L.Q. 883, 886-87 (2002) [hereinafter Pritchard, Who Cares?] (same). There have been, however, notable exceptions in recent years. E.g., Shawn Young, Ex-WorldCom Directors Reach Pact, Wall St. J., Mar. 21, 2005, at A6.

44. Blue Chip Stamps v. Manor Drug Stores, 421 U.S. 723, 744-45 (1975). 
half they are brought. The compensatory shortcomings of the modern Rule $10 \mathrm{~b}-5$ class action have been well chronicled elsewhere and will only briefly be summarized here. First, many members of the plaintiff class will also be shareholders of the defendant corporation when suit is brought. For them, recovery will result largely in "pocket shifting." 45 Second, those class members who are well diversified may not benefit from Rule $10 \mathrm{~b}-5$ litigation in the long run. This is because in a fraud-on-themarket case, "each loser-the buyer or seller disadvantaged by the fraud-is balanced by another winner: the person on the other side of the trade"; ${ }^{46}$ chances are that a well-diversified investor will be a winner as often as a loser, and will "perceive[] little good in a legal rule that forces his winning half to compensate his losing half over and over." 47 Third, there is the practical reality that Rule $10 \mathrm{~b}-5$ class actions recover only an insignificant share of investor losses at very high transaction costs. ${ }^{48}$ For

45. Janet Cooper Alexander, Rethinking Damages In Securities Class Actions, 48 Stan. L. Rev. 1487, 1503-04 (1996) [hereinafter Alexander, Rethinking Damages]; Coffee, Reforming Securities Class Action, supra note 43, at 1558. Even when (as is often the case) insurance is available to fund the settlement, it is not costless for shareholders, who ultimately pay through increased insurance premiums. Langevoort, Capping Damages, supra note 40 , at 648-49; see also Baker \& Griffith, supra note 23, at 489 (finding, based on interviews with insurance market participants, that "D\&O insurers seek to price policies according to the risk posed by each corporate insured").

46. Langevoort, Capping Damages, supra note 40, at 646.

47. Frank H. Easterbrook \& Daniel R. Fischel, Optimal Damages in Securities Cases, 52 U. Chi. L. Rev. 611, 641 (1985) [hereinafter Easterbrook \& Fischel, Optimal Damages]. For additional discussion of this phenomenon, see Alexander, Rethinking Damages, supra note 45, at 1502; Coffee, Reforming Securities Class Action, supra note 43, at 1558-59; Langevoort, Capping Damages, supra note 40, at 646-48; see also Anjan V. Thakor, The Economic Reality of Securities Class Action Litigation 12-14 (Oct. 26, 2005) (research paper released by U.S. Chamber Institute for Legal Reform), available at http://www.heart land.org/Article.cfm?artID=18331 (on file with the Columbia Law Review) (providing empirical evidence that institutional investors break even when trading common stocks affected by alleged fraud). But see Alicia Davis Evans, The Investor Compensation Fund, 33 J. Corp. L. 223, 227-34 (2007) (arguing that diversified investors can suffer substantial losses from fraud, presenting a compelling case for compensation); Alicia Davis Evans, Are Investors' Gains and Losses from Securities Fraud Equal over Time? Some Preliminary Evidence (Apr. 15, 2008) (unpublished manuscript, on file with the Columbia Law Review) (presenting empirical evidence to support same).

48. Alexander, Rethinking Damages, supra note 45, at 1500; Coffee, Reforming Securities Class Action, supra note 43, at 1545. Securities settlement values have risen in recent years, but not at a pace commensurate with investor losses. See Todd Foster, Ronald I. Miller \& Stephanie Plancich, NERA Econ. Consulting, Recent Trends in Shareholder Class Action Litigation: Filings Plummet, Settlements Soar 9 (2007), available at http://www.nera.com/publication.asp?p_ID=3028 (on file with the Columbia Law Review). Revelation of the fraud also imposes a severe market penalty on the firm, and indirectly, its innocent shareholders. See Jonathan M. Karpoff, D. Scott Lee \& Gerald S. Martin, The Cost to Firms of Cooking the Books, $43 \mathrm{~J}$. Fin. \& Quantitative Analysis (forthcoming Sept. 2008) (manuscript at 2, on file with the Columbia Law Review), available at http://ssrn.com/abstract=652121 [hereinafter Karpoff et al., Cooking the Books] (finding that a firm's reputation losses as a result of financial fraud exceed "the legal penalty by over 7.5 times, and [exceed] the amount by which firm value was artificially inflated by more than 2.5 times"). 
these reasons, most commentators now agree that the prototypical Rule $10 \mathrm{~b}-5$ class action (i.e., one brought against a nontrading corporation for its officer's fraud-on-the-market) cannot be defended on compensatory grounds. ${ }^{49}$

As the original compensatory justification for private Rule $10 \mathrm{~b}-5$ enforcement grew less persuasive, a deterrence-based justification took on increased prominence. In 1964, the Supreme Court implied a private right of action to sue for damages under section 14(a) of the 1934 Act in J. I. Case Co. $v$. Borak, based on the view that " $[\mathrm{p}]$ rivate enforcement of the proxy rules provides a necessary supplement to Commission action."50 The same reasoning was subsequently invoked to explain private enforcement of Rule 10b-5.51 "In effect, Borak treats plaintiffs not as victims so much as 'private attorneys general' to whom damages are paid as a reward for bringing lawsuits that serve the public purpose of deterring securities violations"; it thus marked a significant departure from "the traditional compensatory rationale for implied rights of action." ${ }^{2}$ Indeed, the purpose served by securities class actions today is more akin to the purpose served by qui tam actions ${ }^{53}$ than traditional private civil litigation. ${ }^{54}$

49. See, e.g., Alexander, Rethinking Damages, supra note 45, at 1507 ("[T]he compensation rationale does not persuasively justify the present measure of damages."); Coffee, Reforming Securities Class Action, supra note 43, at 1545 ("From a compensatory perspective, the conclusion seems inescapable that the securities class action performs poorly."); Langevoort, Capping Damages, supra note 40, at 651 (noting that compensatory justification for private Rule $10 \mathrm{~b}-5$ class actions "has relatively few informed, non selfserving defenders"); Pritchard, Markets as Monitors, supra note 41, at 928 (arguing that "a rational investor would not willingly pay for the compensation provided by the class action regime if deterrence could be achieved at a lower cost through alternative means"); Pritchard, Who Cares?, supra note 43, at 884 ("Securities class actions cannot be justified as providing compensation.”); cf. Basic Inc. v. Levinson, 485 U.S. 224, 262 (1988) (White, J., dissenting) (warning that adoption of fraud-on-the-market presumption would "lead to large judgments, payable in the last analysis by innocent investors, for the benefit of speculators and their lawyers" (internal quotation marks omitted)).

50. 377 U.S. 426,432 (1964).

51. See Blue Chip Stamps v. Manor Drug Stores, 421 U.S. 723, 737 (1975) (finding growth of private actions under Rule $10 \mathrm{~b}-5$ as "consistent with the congressional enactment" of section 10 (b), and citing Borak for underlying rationale); see also Tellabs, Inc. v. Makor Issues \& Rights Ltd., 127 S. Ct. 2499, 2504, 2507 (2007) (citing Borak as support for proposition that private actions under section $10(\mathrm{~b})$ are indispensible supplement to SEC action); Piper v. Chris-Craft Indus., 430 U.S. 1, 25 (1977) (same).

52. Tamar Frankel, Implied Rights of Action, 67 Va. L. Rev. 553, 557 (1981).

53. As described by Professor Beck:

A qui tam statute permits a private citizen to bring an action on behalf of the government for recovery of a statutory penalty. The person who pursues the action-the "informer" or "relator" - receives a portion of any amount recovered on the government's behalf. Thus, qui tam statutes privatize government litigation, permitting the private informer to sue for the government on a contingent-fee basis.

J. Randy Beck, The False Claims Act and the English Eradication of Qui Tam Legislation, 78 N.C. L. Rev. 539, 541 (2000) (footnotes and emphasis omitted).

54. See Jill E. Fisch, Class Action Reform, Qui Tam, and the Role of the Plaintiff, Law \& Contemp. Probs., Autumn 1997, at 167, 175 (asserting "victim compensation is not the 
This revisionist justification for private Rule $10 \mathrm{~b}-5$ enforcement clearly begged the question: Why is it necessary to task private plaintiffs with a deterrence job already assigned to the Commission? That question, however, sparked little debate at the time. Perhaps the answer appeared too obvious to warrant serious discussion. After all, the 1960s and early 1970s were marked by a profound skepticism of the administrative state, as notions of "regulatory capture" gained popular acceptance, ${ }^{55}$ along with an almost starry-eyed optimism about the possibilities for class litigation "to deter wrongdoers who previously were effectively insulated from responsibility by the economics of disputing." 56 Congress even began experimenting with direct citizen enforcement of environmental laws. ${ }^{57}$ As explained in Part II, there are important differences between enforcement of the environmental laws through citizen suits and enforcement of Rule $10 \mathrm{~b}-5$ through class action litigation, but such nuances were subsumed at the time by a transsubstantive belief in the efficacy of the "private attorney general." 58

\section{B. The Private Attorney General Falls into Disrepute}

In the 1970s, however, judicial and political attitudes changed. Disenchantment with the "private attorney general" concept began to mani-

motivation" behind representative litigation); see also Alexander, Rethinking Damages, supra note 45, at 1508 (explaining that " $[c]$ lass actions involving open-market transactions in the secondary market do not ... fit the common law model" and that the "wrongful act in these open-market cases . . . is the violation of a regulatory statute enacted for the benefit of the public at large"); Matthew C. Stephenson, Public Regulation of Private Enforcement: The Case for Expanding the Role of Administrative Agencies, 91 Va. L. Rev. 93, 103-04 (2005) (noting extensive scholarship which concludes that "deterrence, rather than the need for private redress, has been the Court's primary rationale for recognizing private causes of action under the securities and investor protection laws; private plaintiffs in these cases are seen by courts not so much as 'victims' in need of compensation but rather as private attorneys general" (citation omitted)).

55. See Richard A. Posner, The Rise and Fall of Administrative Law, 72 Chi.-Kent L. Rev. 953, 955-56 (1997); Jeremy A. Rabkin, Government Lawyering: The Secret Life of the Private Attorney General, 61 Law \& Contemp. Probs., Winter/Spring 1998, at 179, 184.

56. Jeffrey W. Stempel, Class Actions and Limited Vision: Opportunities for Improvement Through a More Functional Approach to Class Treatment of Disputes, 83 Wash. U. L.Q. 1127, 1269 (2005); see also James D. Cox, Making Securities Fraud Class Actions Virtuous, 39 Ariz. L. Rev. 497, 498 (1997) [hereinafter Cox, Making Class Actions Virtuous] ("It is not mere coincidence that the most significant expansion in class action procedures occurred in the 1960s, a decade of great social change in America, a decade defined by its idealism and marked by the expansion of rights for all its citizens.").

57. Matthew D. Zinn, Policing Environmental Regulatory Enforcement: Cooperation, Capture, and Citizen Suits, 21 Stan. Envtl. L.J. 81, 83-84 (2002).

58. Although some have tried to define the concept more precisely, see, e.g., William B. Rubenstein, On What a "Private Attorney General" Is-And Why It Matters, 57 Vand. L. Rev. 2129 (2004) [hereinafter Rubenstein, Private Attorney General], "private attorney general" in this context simply means a private party who sues primarily to vindicate a public interest, rather than to redress a personal loss. 
fest itself in varied ways. ${ }^{59}$ For example, the Supreme Court began limiting the standing of individuals to sue to enforce the public interest; by requiring that plaintiffs show some individualized injury traceable to the alleged violation, the Court effectively precluded Congress from pushing private enforcement of public law to its outermost limits. ${ }^{60}$ The Supreme Court also retreated from Borak, refusing to recognize new implied private causes of action under the securities laws absent some indication of a congressional intent to create such rights. ${ }^{61}$ Moreover, an expansive reading of Federal Rule of Civil Procedure 23 came under sustained attack. Opponents of the class device "rallied around characterizations of the procedure as a form of 'legalized blackmail" "and charged "widespread abuse of the rule by lawyers and litigants on both sides of the "v.,' including unprofessional practices related to attorneys' fees, 'sweetheart' settlement deals, dilatory motion practice, harassing discovery, and misrepresentations to judges." 62 Rule $10 \mathrm{~b}-5$ class actions were singled out as presenting a particularly pernicious "danger of vexatiousness." 63

Significantly, policymakers critical of Rule $10 \mathrm{~b}-5$ class actions did not challenge the assumption that private enforcement is a necessary supplement to the Commission's deterrence efforts. Moreover, it was not seriously questioned that the best vehicle for private enforcement remained the class action device (as opposed to something more akin to a qui tam suit). It is, quite frankly, rather surprising that more pressure was not brought to bear on these assumptions, although the historic support of private enforcement by the Commission ${ }^{64}$ and an outdated belief that

59. For further discussion on this shift, see Cox \& Thomas, SEC Enforcement Heuristics, supra note 36, at 740; Mahoney, supra note 38, at $664 \&$ n. 102 .

60. See, e.g., Sierra Club v. Morton, 405 U.S. 727, 731-41 (1972) (denying standing to plaintiff environmental organization that failed to assert individualized harm to itself or its members).

61. See, e.g., Transamerica Mortgage Advisors, Inc. v. Lewis, 444 U.S. 11, 19-24 (1979) (refusing to find implied right of action under section 206 of Investment Advisors Act of 1940); Touche Ross \& Co. v. Redington, 442 U.S. 560, 568-78 (1979) (denying implied right of action under section 17(a) of the Exchange Act; explaining that "in a series of cases since Borak we have adhered to a stricter standard for the implication of private causes of action, and we follow that standard today"); Piper v. Chris-Craft Indus., 430 U.S. 1, 24-42 (1977) (holding that defeated tender offeror has no implied cause of action for damages under section 14(e)). For commentary on these judicial developments, see Roberta S. Karmel, Regulation By Prosecution: The Securities Exchange Commission vs. Corporate America 193-95 (1982); Frankel, supra note 52, at 553; Grundfest, Rights of Action, supra note 31, at 988.

62. Arthur Miller, Of Frankenstein Monsters and Shining Knights: Myth, Reality, and the "Class Action Problem," 92 Harv. L. Rev. 664, 665-66 (1979).

63. Blue Chip Stamps v. Manor Drug Stores, 421 U.S. 723, 739 (1975).

64. See Securities Litigation Abuses: Hearing Before the Subcomm. on Securities of the S. Comm. on Banking, Housing, and Urban Affairs, 105th Cong. (1997) (prepared remarks of Arthur Levitt, Jr., Chairman, Securities and Exchange Commission), at http:// banking.senate.gov/97_07hrg/072497/witness/levitt.htm (on file with the Columbia Law Review) (reiterating that "the Commission has long maintained that private actions provide valuable and necessary additional deterrence ... thereby supplementing the Commission's 
private Rule 10b-5 litigation serves a meaningful compensatory function likely goes part of the way to explain it. ${ }^{65}$ Perhaps the most important development, however, that caused " $[t]$ he social value of private enforcement of the federal securities laws [to] become an article of faith in the federal securities liturgy"66 was the scholarship of John Coffee.

Professor Coffee entered the fray in the early 1980s and framed the terms of the class action debate in a way designed to "rescue" rather than eliminate the besieged "private attorney general." 67 His scholarship on the agency costs in class litigation posited that a misalignment of incentives between class members and class counsel was to blame for the "shortfall between the promise and the performance of the private attorney general" 68 and instructed that "the basic goal of reform should be to reduce the agency costs incident to this attorney-client relationship."69 Professor Coffee's work was stunningly successful in shifting the focus of both the academy and policymakers from the predicate question of the propriety of deterrence-focused class actions, like those brought under Rule $10 \mathrm{~b}-5$, to the narrower question of how best to tweak the economic incentives of class counsel in order to improve them. ${ }^{70}$ Indeed,

own enforcement efforts"); Grundfest, Rights of Action, supra note 31, at 969 (noting support for private enforcement voiced by Congress and courts).

65. See H.R. Rep. No. 104-369, at 31 (1995) (Conf. Rep.), reprinted in 1995 U.S.C.C.A.N. 679, 730 ("Private securities litigation is an indispensable tool with which defrauded investors can recover their losses without having to rely upon government action."); Brief of the United States Securities \& Exchange Commission at 2-4, S.E.C. v. Rind, 991 F.2d 1486 (9th Cir. 1993) (No. 91-55972) (noting that "enforcement actions are significantly different from private damage actions," because the Commission seeks to "vindicate the public interest in the enforcement of the securities laws rather than the personal interests of private parties in obtaining compensation"); SEC, Report Pursuant to Section 308(c) of the Sarbanes-Oxley Act of 2002, at 20 (2003), available at http:// www.sec.gov/news/studies/sox308creport.pdf (on file with the Columbia Law Review) [hereinafter SEC, SOX Report] ("In contrast to Commission enforcement actions which have several aims, the aim of private litigation is solely to compensate injured investors."). And, of course, securities litigation is big business for plaintiffs' and defendants' lawyers alike. See Coffee, Reforming Securities Class Action, supra note 43, at 1540-41 (discussing enormous costs of securities litigation). These powerful lobbies have a vested interest in maintaining private enforcement. Frank H. Easterbrook \& Daniel R. Fischel, Mandatory Disclosure and the Protection of Investors, $70 \mathrm{Va}$. L. Rev. 669, 671-72 (1984) [hereinafter Easterbrook \& Fischel, Mandatory Disclosure].

66. Grundfest, Rights of Action, supra note 31, at 969.

67. See John C. Coffee, Jr., Rescuing the Private Attorney General: Why the Model of the Lawyer as Bounty Hunter Is Not Working, 42 Md. L. Rev. 215 (1983) [hereinafter Coffee, Rescuing].

68. Id. at 220.

69. John C. Coffee, Jr., Understanding the Plaintiff's Attorney: The Implications of Economic Theory for Private Enforcement of Law Through Class and Derivative Actions, 86 Colum. L. Rev. 669, 726 (1986) [hereinafter Coffee, Plaintiff's Attorney].

70. Ironically, some class action defenders have recently charged that Professor Coffee's scholarship reflected a wrongheaded obsession with compensation. Observing that the true purpose of the small claims class action is deterrence, they argue that it makes little sense to talk of aligning the interests of class counsel with the interests of class members; it is society's interest in deterrence, not class members' narrow interest in 
"[s]cholars from various political viewpoints, who employ many methodologies beyond law and economics and who otherwise agree about very little, could all agree that the central problem in class action jurisprudence was the agency dilemma." 71

\section{The Private Securities Litigation Reform Act of 1995}

The agency costs scholarship pioneered by Professor Coffee clearly influenced the securities litigation reform debate in the 1990s. The Private Securities Litigation Reform Act of 1995 (PSLRA), ${ }^{72}$ enacted over President Clinton's veto as part of the 104th Congress's "Contract With America," implicitly accepts private Rule 10b-5 enforcement as socially desirable. ${ }^{73}$ The Joint Explanatory Statement of the Committee of Conference states that "private lawsuits promote public and global confidence in our capital markets and help to deter wrongdoing and to guarantee that corporate officers, auditors, directors, lawyers and others properly perform their jobs." ${ }^{4}$ The statute therefore attempts to improve, rather than eliminate, private enforcement by better aligning class coun-

monetary recovery, that matters, they explain. See Myriam Gilles \& Gary B. Friedman, Exploding the Class Action Agency Costs Myth: The Social Utility of Entrepreneurial Lawyers, 155 U. Pa. L. Rev. 103, 105 (2006) ("There is but one true objective here-one valid normative measure by which to gauge any class action procedure or practice, or any proposed reform. All that matters is whether the practice causes the defendant-wrongdoer to internalize the social costs of its actions."); see also William B. Rubenstein, Why Enable Litigation?: A Positive Externalities Theory of the Small Claims Class Action, 74 UMKC L. Rev. 709, 710-11 \& n.9 (2006) [hereinafter Rubenstein, Litigation] (defending class actions based on positive externalities which include, but go beyond, both compensation and deterrence). There is an easy answer to this argument, however, that fully reconciles the agency costs approach with a dedication to deterrence-oriented class actions: In class action litigation, the only proxy available for society's interest is the class members' money damages, as defined by the substantive law. The agency costs approach can also, however, be reconciled with a perspective that values compensation as an end in itself. The political debates surrounding class action reform tend to emphasize the latter view. Perhaps this versatility of the agency costs approach has helped dampen more fundamental challenges to the small claims class action. Cf. John C. Coffee Jr., Rethinking the Class Action: A Policy Primer on Reform, 62 Ind. L.J. 625, 644-45 (1987) ("My purpose is not to debunk any set of normative values-either those underlying a 'public law' approach or those espoused by adherents of individual justice-but to examine the likely consequences of proposed mechanisms for implementing normative visions.").

71. Rubenstein, Private Attorney General, supra note 58, at 2163; see also Bryant Garth, Ilene H. Nagel \& S. Jay Plager, The Institution of the Private Attorney General: Perspectives from an Empirical Study of Class Action Litigation, 61 S. Cal. L. Rev. 353, 366 (1988) (observing that liberals and conservatives alike came to "define and promote their views almost exclusively in terms of whether there is enough or too much of a market incentive for individual attorneys to take particular lawsuits").

72. Pub. L. No. 104-67, 109 Stat. 737 (codified as amended in scattered sections of 15 U.S.C. and 18 U.S.C.).

73. Michael A. Perino, Did the Private Securities Litigation Reform Act Work?, 2003 U. Ill. L. Rev. 913, 918-19 [hereinafter Perino, Did the PSLRA Work?].

74. H.R. Rep. No. 104-369, at 31 (1995) (Conf. Rep.), reprinted in 1995 L.S.C.C.A.N. 679,730 . 
sel's and class members' interests. Most notably, the PSLRA's "lead plaintiff" provision is designed to ensure that the party with the largest stake in the litigation selects and monitors class counsel, so that litigation decisions better reflect the interests of the plaintiff class. ${ }^{75}$ Lack of client control has been identified in the agency costs literature as the source of all major shortcomings of class litigation, including the initiation of meritless suits and collusive settlements. ${ }^{76}$

In addition to these "client empowerment" reforms, ${ }^{77}$ the PSLRA also contains several substantive and procedural requirements for private Rule 10b-5 actions that, collectively, were designed to make it more difficult to bring certain categories of cases thought to be most troublesome. For example, disclosure of "soft" information (such as revenue forecasts) may render a company particularly susceptible to suits alleging "fraud-byhindsight." 78 The PSLRA therefore creates a safe harbor from liability for forward-looking statements either accompanied by meaningful cautionary language or made without actual knowledge of their falsity. ${ }^{79}$ The safe harbor is designed "to encourage issuers to disseminate relevant information to the market without fear of open-ended liability." 80

The statute also heightens the pleading standards for stating a Rule $10 \mathrm{~b}-5$ claim with the aim of weeding out weak cases on a motion to dismiss. ${ }^{81}$ Specifically, it requires that the complaint allege with specificity: the statement or omission that is false or misleading and why; ${ }^{82}$ if pleaded on information and belief, particularity as to facts on which that belief is formed; ${ }^{83}$ and facts giving rise to a strong inference that the defendant acted with the required state of mind. ${ }^{84}$ The PSLRA also requires plaintiffs to plead and prove loss causation, ${ }^{85}$ and generally precludes discovery pending decision on a motion to dismiss. ${ }^{86}$

While designed to eliminate meritless cases early, specifically those based on a mere drop in a company's stock price, some have warned that these reforms may also cut off meritorious suits and thus compromise the

75. See Perino, Did the PSLRA Work?, supra note 73, at 923-24.

76. See, e.g., Coffee, Rescuing, supra note 67, at 229-30 (explaining that lack of client control leads to consequences that "weaken and potentially cripple private enforcement of law by means of the private attorney general").

77. Fisch, supra note 54, at 176.

78. Ann Morales Olazábal, Safe Harbor for Forward-Looking Statements Under the Private Securities Litigation Reform Act of 1995: What's Safe and What's Not?, 105 Dick. L. Rev. 1, 4-6 (2000).

79. See id. at $5-6$.

80. H.R. Rep. No. 104-369, at 32 (1995) (Conf. Rep.), reprinted in 1995 U.S.C.C.A.N. 679, 730 .

81. Perino, Did the PSLRA Work?, supra note 73, at 924.

82. 15 U.S.C. $\S 78 u-4(b)(1)(2006)$.

83. Id.

84. Id. $\$ 78 \mathrm{u}-4$ (b) (2); see Tellabs, Inc. v. Makor Issues \& Rights, Ltd., 127 S. Ct. 2499 , 2507-10 (2007).

85. $§ 78 u-4$ (b) (4); see Dura Pharms., Inc. v. Broudo, 544 U.S. 336, 341-43 (2005).

86. $\$ 78 \mathrm{u}-4(\mathrm{~b})(3)(\mathrm{B})$. 
deterrent effect of the law. ${ }^{87}$ Indeed, several scholars have suggested that the catastrophic corporate failures of the early 2000s, including Enron, WorldCom, and others, may be attributable at least in part to the PSLRA. 88

By altering the substantive law and erecting procedural barriers to its enforcement based on concerns about securities class action "abuse," Congress hardly broke with tradition: The judiciary had been doing the same for decades. ${ }^{89}$ The Supreme Court's decision in Blue Chip Stamps $v$. Manor Drug Stores, Inc., denying standing to enforce Rule $10 \mathrm{~b}-5$ to nonpurchasers and nonsellers of securities, for example, was explicitly motivated by a concern about "strike suits." sions restricting the scope of Rule $10 \mathrm{~b}-5$ were influenced by similar concerns, such as the 1994 decision in Central Bank of Denver, N.A. v. First Interstate Bank of Denver, N.A., holding that Section 10(b) does not permit the imposition of aiding and abetting liability. ${ }^{91}$ Like the PSLRA, Central Bank has been criticized as contributing to the spate of corporate failures earlier this decade. ${ }^{92}$

87. See, e.g., Langevoort, Capping Damages, supra note 40, at 640-41; Pritchard, Markets as Monitors, supra note 41, at 961-62.

88. See John C. Coffee, Jr., Gatekeeper Failure and Reform: The Challenge of Fashioning Relevant Reforms, 84 B.U. L. Rev. 301, 318-20 (2004) [hereinafter Coffee, Gatekeeper Failure] (attributing increased auditor acquiescence in aggressive accounting practices in part to effects of the PSLRA); Perino, Did the PSLRA Work?, supra note 73, at 914, 935-36 (noting charges that the PSLRA has made fraud easier, and finding some evidence consistent with this claim); see also Hillary A. Sale, Heightened Pleading and Discovery Stays: An Analysis of the Effect of the PSLRA's Internal-Information Standard on '33 and '34 Act Claims, 76 Wash. U. L.Q. 537, 564 (1998) (predicting that "the strict application of the heightened-pleading standard in combination with the stay-of-discovery provision is likely to result in unredressed fraud").

89. See Stephen Berry, Ending Substance's Indenture to Procedure: The Imperative for Comprehensive Revision of the Class Damage Action, 80 Colum. L. Rev. 299, 310 n.69 (1980) (noting one example of the foregoing in the antitrust context); Coffee, Rescuing, supra note 67, at 228 (noting tendency of courts "to narrow and limit substantive statutory rights, seemingly because of their distaste for the process by which such rights are enforced").

90. 421 U.S. 723, 740 (1975). "Strike suits" are "meritless suits brought by class action plaintiffs' lawyers to extort settlement and attorneys' fees." Rose, supra note 39, at 455.

91. 511 U.S. 164, 188-90 (1994) (noting that Rule 10b-5 litigation presents a "danger of vexatiousness" and "requires secondary actors to expend large sums even for pretrial defense and the negotiation of settlements").

92. See Coffee, Gatekeeper Failure, supra note 88, at 318-20 (observing that Central Bank may have contributed to "gatekeeper failure" that led to scandals like Enron). The Supreme Court interpreted the reach of Central Bank broadly this past Term in Stoneridge Investment Partners, LLC v. Scientific-Atlanta, Inc., 128 S. Ct. 761, 768-74 (2008). See also Larry E. Ribstein, Fraud on a Noisy Market, 10 Lewis \& Clark L. Rev. 137, 153-54 (2006) (explaining how concerns regarding vexatious litigation influenced the Court's decision in Dura). 


\section{The Status Quo}

Whether the PSLRA has actually reduced the number of securities strike suits presents a difficult empirical question. ${ }^{93}$ Indeed, there is not even a consensus that strike suits were a problem in need of solving when the PSLRA was enacted. ${ }^{94}$ Most seem to agree, however, that the current system of Rule 10b-5 enforcement still does not result in optimal deterrence, and hence calls for reform to continue. ${ }^{95}$ As noted, some believe

93. For empirical analyses addressing this topic, see Perino, Did the PSLRA Work?, supra note 73, at 915 (concluding "there are as many, if not more, class actions filed annually after passage of the PSLRA as before" but also that the PSLRA may have improved "overall case quality" in some instances); Stephen J. Choi, Do the Merits Matter Less After the Private Securities Litigation Reform Act? 27-29 (NYU Law \& Econ. Paper No. 03-04, 2005), available at http://ssrn.com/abstract $=558285$ (on file with the Columbia Law Review) (concluding that the PSI.RA did not "selectively [eliminate] only nuisance litigation"). Securities class action filings hit a ten-year low in 2006, according to studies by Cornerstone Research, NERA Economic Consulting, and PricewaterhouseCoopers LLP. See Cornerstone Research, 2006: A Year in Review 3 (2007), available at http://securities. stanford.edu/clearinghouse_research/2006_YIR/2007010201.pdf (on file with the Columbia Law Review); Foster et al., supra note 48, at 2 (2007); PricewaterhouseCoopers LLP, 2006 Securities Litigation Study 5 (2007), available at http://www.pwc.com/images/ us/eng/about/svcs/advisory/pi/SecLitStudy_2006_Final.pdf (on file with the Columbia Law Review) [hereinafter PWC, 2006 Study]. Several explanations have been offered for the drop, including better corporate governance, tougher federal enforcement, a strong stock market combined with lower stock price volatility, and preoccupation on the part of the plaintiffs' bar due to (inter alia) the criminal indictment of Milberg Weiss. See, Cornerstone, supra, at 1; N.Y. City Econ. Dev. Corp., Sustaining New York's and the US's Global Financial Services Leadership 74-75 (2007), available at http://www.nyc.gov/html/ $\mathrm{om} / \mathrm{pdf} / \mathrm{ny}$ _report_final.pdf (on file with the Columbia Law Review) [hereinafter NYCEDC]. The decline in the number of filings has not continued, however, and in 2007 filings returned to 2005 levels. See Stephanie Plancich, Brian Saxton \& Svetlana Starykh, NERA Econ. Consulting, Recent Trends In Shareholder Class Actions: Filings Return to 2005 Levels as Subprime Cases Take Off; Average Settlements Hit New High 2 (2007), available at http://www.nera.com/image/PUB_Recent_Trends_Dec2007_FINAL.pdf (on file with the Columbia Law Review).

94. Compare Janet Cooper Alexander, Do the Merits Matter? A Study of Settlements in Securities Class Actions, 43 Stan. L. Rev. 497, 499-500 (1991) (concluding that settlement value in securities fraud cases is not function of merit), with Leonard B. Simon \& William S. Dato, Legislating on a False Foundation: The Erroneous Academic Underpinnings of the Private Securities Litigation Reform Act, 33 San Diego L. Rev. 959, 960-62 (1996) (arguing Alexander's study is fundamentally flawed and that Congress relied on its erroneous results).

95. See Coffee, Reforming Securities Class Action, supra note 43, at 1535-36 ("As presently constituted, securities class actions produce wealth transfers among shareholders that neither compensate nor deter."); Pritchard, Markets as Monitors, supra note 41, at 958 (noting that "class actions offer, at best, a very imprecise and expensive form of deterrence"); Richard A. Booth, Who Should Recover What for Securities Fraud? 8 (Univ. of Md. Legal Studies Research Paper No. 2005-32, 2005), available at http://ssrn.com/ abstract=683197 (on file with the Columbia Law Review) (suggesting that securities fraud class actions "do no apparent good for anyone (other than lawyers), but they do considerable harm to defendant companies"). It was reported that the SEC would hold a roundtable discussion in Spring 2008 to discuss securities litigation reform, at the behest of a diverse group of law professors. See Kara Scannell, SEC to Study Revamp on 
that the PSLRA, like Central Bank before it, went too far to insulate misbehavior from liability, leading to underdeterrence. Others charge that excessive securities litigation continues to overdeter, harming the competitiveness of U.S. capital markets by driving issuers abroad. ${ }^{96}$ Still others observe that private securities litigation both overdeters and underdeters, depending on the class of defendants. ${ }^{97}$

Commentators on all sides have criticized the out-of-pocket damages measure employed in Rule $10 \mathrm{~b}-5$ class actions as not conducive to achieving optimal deterrence. In theory, optimal deterrence is achieved when the defendant is made to internalize the net social costs of the contemplated misbehavior-no more, no less. This requires that the sanction equal the net social costs of the conduct multiplied by the inverse of the probability of its imposition (or, rather, that the defendant perceives this to be the case). ${ }^{98}$ But the damages measure in private Rule $10 \mathrm{~b}-5$ litiga-

Shareholder Suits, Wall St. J., Sept. 24, 2007, at C2. Chairman Cox postponed the roundtable pending the confirmation of Democratic Commissioners to ensure "a balanced commission that would give the public confidence that we were handling this very important issue with great care and not in any political way." The Commodity Futures Trading Commission and Securities Exchange Commission's Budget Requests and Justifications for Fiscal Year 2009: Hearing Before the Subcomm. on Financial Servs. and General Government of the S. Comm. on Appropriations, 110th Cong. (May 7, 2008), available at LEXIS, Federal News Service (testimony of Christopher Cox, Chairman, United States Securities and Exchange Commission). The Commission's two Democratic vacancies have now been filled. Press Release, U.S. SEC, Statement from Chairman Cox Regarding Senate Confirmation of SEC Commissioner Nominees (June 27, 2008), available at http://www.sec.gov/news/press/2008/2008-125.htm (on file with the Columbia Law Review). But to date, the roundtable has not occurred.

96. See Comm'n on the Regulation of U.S. Capital Mkts. in the 21st Century, Report and Recommendations 28-31 (2007), available at http://www.uschamber.com/publica tions/reports/0703capmarketscomm.htm (on file with the Columbia Law Review) ("International observers increasingly cite the U.S. legal and regulatory environment as a critical factor discouraging companies and other market participants from accessing U.S. markets."); NYCEDC, supra note 93 , at 74-75 (arguing that, despite decrease in securities litigation filings in 2005-2006, fear of litigation puts New York City at a disadvantage vis-àvis London); Luigi Zingales et al., Interim Report of the Committee on Capital Markets Regulation, at x-xi (2006), available at http://www.capmktsreg.org/pdfs/11.30Committee _Interim_ReportREV2.pdf (on file with the Columbia Law Review) [hereinafter Zingales et al., Interim Report] (citing liability risk as factor contributing to decrease in U.S. public equity market competitiveness); see also Comm. on Capital Mkts. Regulation, The Competitive Position of the U.S. Public Equity Market 1-5 (2007), available at http:// www.capmktsreg.org/pdfs/The_Competitive_Position_of_the_US_Public_Equity_Market. pdf (on file with the Columbia Law Review) (providing additional data demonstrating loss of public equity market competitiveness).

97. See, e.g., Coffee, Law and the Market, supra note 7, at 305.

98. "Thus, if the harm is 100 and the probability of sanctions is 50 percent, the sanction should be multiplied by $1 / .5=2$, so the sanction should equal 200 (and thus the expected sanction would equal 100)." Steven Shavell, Foundations of Economic Analysis of Law 483 (2004). This assumes that those sought to be deterred are risk neutral and solvent. Id. at 483-84. 
tion bears little relationship to the harm sought to be deterred. ${ }^{99}$ That harm is not the loss sustained by any discrete set of investors (which will be offset by the gain to investors on the other side of the transactions), but the more amorphous harm suffered by all investors-indeed, all members of society-when fraud raises the cost of capital and upsets the allocative efficiency of the economy. ${ }^{100}$ Another related critique is that it is most often the corporation and, indirectly, its shareholders that are forced to internalize these inaccurate damages, rather than the actual individual wrongdoers, who usually escape personal liability altogether. ${ }^{101}$

Various solutions to these lingering problems have been offered. For example, Professor Coffee has suggested ways to cause culpable insiders to shoulder more of the liability, including most radically the elimination of enterprise liability in private fraud-on-the-market cases involving a nontrading issuer. ${ }^{102} \mathrm{He}$ has also advocated imposing strict liability for Rule $10 \mathrm{~b}-5$ violations on auditors to prompt them to play a more robust gatekeeping role, with a cap on liability to avoid overdeterrence (and possible bankruptcy, with its attendant negative effects on the competitive-

99. See, e.g., Alexander, Rethinking Damages, supra note 45, at 1498 (“Aggregate class trading losses are probably greater than either the true net social cost of the violation or the benefits received by the violator, both of which are speculative in nature and difficult to calculate."); Langevoort, Capping Damages, supra note 40, at 646 ("[F]ull outof-pocket compensation in open-market cases is systematically excessive and dysfunctional ....").

100. See Richard A. Posner, Economic Analysis of Law 660 (7th ed. 2007) [hereinafter Posner, Economic Analysis]; Easterbrook \& Fischel, Mandatory Disclosure, supra note 65, at 673-79; Fischel, Modern Finance Theory, supra note 40, at 16; Pritchard, Markets as Monitors, supra note 41 , at $937-45$. That harm is difficult to measure. See Mahoney, supra note 38, at 657-58 (discussing these difficulties). There are also significant practical difficulties in calculating damages under the current measure that make it difficult for defendants to predict their exposure, Alexander, Rethinking Damages, supra note 45 , at $1490-93$, further complicating the deterrence calculus.

101. Almost without exception, Rule $10 \mathrm{~b}-5$ class actions that are not dismissed at the pleading stage result in settlement, and the individual wrongdoers allegedly responsible for the fraud rarely contribute. See Coffee, Reforming Securities Class Action, supra note 43, at 1566-70 (explaining how combination of agency costs, legal rules regarding indemnification, and insurance practices lead corporation, rather than insiders, to shoulder brunt of Rule $10 \mathrm{~b}-5$ liability). Instead, the primary sources of settlement payments are issuers, their insurers, and ancillary defendants. Alexander, Rethinking Damages, supra note 45 , at $1506 \& \mathrm{n} .81$. Each of these sources of funds can be traced back to innocent investors: Payments by the issuer effect a direct transfer of wealth from the issuer's current shareholders to the class members; payments by insurers are funded by premiums paid by the insurer's policyholders (issuers and, indirectly, their innocent shareholders); and payments by ancillary defendants, like accountants and investment banks, are charged back to issuers (and, indirectly, their innocent shareholders) through increased fees due to litigation risk. Langevoort, Capping Damages, supra note 40, at 648-49.

102. See Coffee, Reforming Securities Class Action, supra note 43, at 1583. 
ness of the market for auditing services). ${ }^{103}$ Professor Partnoy has made a similar proposal. ${ }^{104}$ Professor Langevoort has suggested capping compensatory damages in cases involving a nontrading issuer, ${ }^{105}$ and Professor Alexander has suggested replacing them with civil penalties tiered to distinguish between defendants with different states of mind. ${ }^{106}$ She would leave private parties to enforce the penalties, subject to limited Commission oversight. ${ }^{107}$ Professor Pritchard would similarly replace damages with penalties, but would leave it to the exchanges, rather than individuals, to enforce. ${ }^{108}$

These proposals present interesting solutions to the deterrence shortcomings of Rule 10b-5 class actions. But each perpetuates the assumption that the Commission cannot or should not handle Rule $10 \mathrm{~b}-5$ deterrence efforts on its own. ${ }^{109}$ That assumption may be valid, but it ought to be seriously tested before further reform efforts are built on it. ${ }^{10}$ Part II undertakes this task, analyzing at a theoretical level the rela-

103. See Coffee, Gatekeeper Failure, supra note 88, at 349-53. See generally Eric L. Talley, Cataclysmic Liability Risk Among Big Four Auditors, 106 Colum. L. Rev. 1641 (2006) (exploring claim that auditing profession faces such significant risk of cataclysmic liability that its long term viability is imperiled).

104. See Frank Partnoy, Barbarians at the Gatekeepers?: A Proposal for a Modified Strict Liability Regime, 79 Wash. U. L.Q. 491, 540-46 (2001) (outlining strict liability regime that would encourage competition among gatekeepers and creation of reinsurance market for securities fraud risk in order to avoid overdeterrence).

105. See Langevoort, Capping Damages, supra note 40.

106. See Alexander, Rethinking Damages, supra note 45, at 1508-13.

107. See id. at 1516-19 \& n.133.

108. See Pritchard, Markets as Monitors, supra note 41. More recently, Professor Pritchard has proposed that shareholders be entitled to vote on the damages measure to be utilized in securities fraud suits brought against their company. A.C. Pritchard, Stoneridge Investment Partners, LLC v. Scientific-Atlanta, Inc.: The Political Economy of Securities Class Action Reform, in Cato Supreme Court Review (Ilya Shaprio ed., forthcoming Sept. 2008), available at http://ssrn.com/abstract=1159983 (on file with the Columbia Law Review) [hereinafter Pritchard, Political Economy].

109. See, e.g., Alexander, Rethinking Damages, supra note 45, at 1490 (taking "as given ... the need for a private litigation remedy as a supplement to SEC enforcement"); Langevoort, Capping Damages, supra note 40, at 652 (assuming that "the conventional view that private litigation is a necessary supplement to SEC enforcement is well-grounded" because of Commission resource constraints).

110. A few commentators have questioned the desirability of private enforcement of Rule 10b-5. Professor Grundfest urged the Commission to at least consider disimplying the private Rule $10 \mathrm{~b}-5$ cause of action prior to the enactment of the PSLRA, explaining that "the relationship between private and federal enforcement of the securities laws has not been subject to rigorous analysis." Grundfest, Rights of Action, supra note 31, at 969 . In a more recent editorial, he has again questioned whether private enforcement should be retained. Joseph A. Grundfest, Op-Ed., The Class-Action Market, Wall St. J., Feb. 7, 2007, at A15. Over a quarter century ago, Professor Frankel concluded that "[t]he experiment with deterrence-oriented private actions as a supplement to public enforcement of the securities acts has not been successful." Frankel, supra note 52, at 585. Professors Stewart and Sunstein have also questioned the wisdom of private enforcement of the securities laws in cases alleging fraud-on-the-market. See Richard B. Stewart \& Cass R. Sunstein, Public Programs and Private Rights, 95 Harv. L. Rev. 1193, 1303-04 (1982) 
tive costs and benefits of a system of private Rule $10 \mathrm{~b}-5$ enforcement versus a system of exclusive Commission enforcement. Although a lack of empirical data precludes reaching a definitive conclusion as to the superior method of enforcement, the analysis nonetheless contributes considerably to the reform debate. It offers a different perspective on the perceived shortcomings of Rule $10 \mathrm{~b}-5$ class actions, and, as explained further in Part III, suggests a way to approach securities class action reform that is potentially superior to those previously considered by policymakers.

\section{Is Private Enforcement Really a "Necessary Supplement" to COMMISSION ACTION?}

When private rights of action offer meaningful compensation to injured parties, they may be defended based on corrective justice grounds, entirely apart from considerations of optimal deterrence. ${ }^{111}$ Moreover, truly compensatory private actions tend to promote the goal of deterrence: "The award of damages to those who actually incur the costs (assuming damages are properly computed) will provide incentives for defendants to maintain an efficient level of compliance," and will do so without risking excessive enforcement given that a rational plaintiff will not sue unless "the social costs sought to be internalized (expected damage awards) . . . exceed the plaintiff's expected litigation costs." 112 As discussed in the previous section, however, most commentators now agree that the prototypical Rule 10b-5 class action does not provide meaningful compensation to investors. ${ }^{113}$ In contrast to a common law fraud case, a "fraud-on-the-market" Rule $10 \mathrm{~b}-5$ class action is less about correcting forced wealth transfers between the plaintiffs and the defendants than it is about protecting the integrity of our capital markets.

If one accepts this premise, then the desirability of retaining private Rule $10 \mathrm{~b}-5$ enforcement via the class device is, or ought to be, immediately called into question. There are few instances, at least since our Republic developed a mature public law enforcement capability, in which

(noting overdeterrence and excessive enforcement costs associated with private rights of action). The Committee on Capital Markets Regulation has similarly observed that "the public value of the securities class action is questionable," Zingales et al., Interim Report, supra note 96 , at 78 , and has recommended giving shareholders the right to opt out of the class action regime in favor of arbitration, id. at 18. The Commission had been rumored to be considering this; Chairman Cox, however, has denied that there is pending before the Commission "any proposal or other mature rule" on the subject. Kara Scannell, Siobhan Hughes \& David Reilly, SEC Probes CDOs and Bear Funds; Cox Testifies Agency Has "About 12" Inquiries; Accurate Pricing Is an Issue, Wall St. J., June 27, 2007, at A3.

111. See supra notes 33-34 and accompanying text. "American tort law recognizes the corrective justice ideal by providing a mechanism through which defendants who have wrongfully injured plaintiffs are required to compensate those plaintiffs for their injuries, and thereby make them whole insofar as this is practically possible." Benjamin C. Zipursky, Civil Recourse, Not Corrective Justice, 91 Geo. L.J. 695, 695 (2003).

112. Stewart \& Sunstein, supra note 110, at 1298-99.

113. See supra Part I.A. 
Congress has expressly granted private parties the right to sue to enforce public law norms absent a traditional tort-like injury that can be meaningfully redressed through litigation. ${ }^{114}$ The few situations in which Congress has done so (e.g., the treble damages antitrust suit, the qui tam action under the False Claims Act, and the environmental "citizen suit") have engendered much controversy. ${ }^{115}$ This controversy is understandable, for it is often more difficult to achieve optimal deterrence under a regime of private enforcement than under a regime of monopolistic public enforcement.

This Part explains why monopolistic public enforcement is often preferable, drawing on classic law and economics scholarship. It first describes, at an abstract level, why private enforcement may lead to overenforcement and how it can complicate efforts to approximate optimal deterrence. Next, it probes the assumptions on which the foregoing conclusions are based, and tests them in the specific context of Rule 10b-5 enforcement. The analysis casts doubt on the conventional wisdom that private Rule $10 \mathrm{~b}-5$ enforcement is obviously superior to the alternative of exclusive Commission enforcement.

\section{A. The Shortcomings of Bounty Enforcement}

Private law enforcement for "bounty" is problematic for two overarching reasons. First, at a theoretical level, it complicates efforts to achieve an enforcement equilibrium. Second, and more practically, it tends to create a relatively rigid system of enforcement. Both factors may lead to overenforcement and, as a result, overdeterrence.

1. The Instability Problem. - Optimal deterrence requires that the sanction imposed equal the net social costs of the misconduct multiplied by the inverse of the probability of the sanction's imposition (or, more precisely, that the defendant perceives this to be the case). ${ }^{116}$ This inverse relationship makes it theoretically possible for a monopolistic public enforcer to save enforcement costs by reducing the probability of en-

114. See Beck, supra note 53, at 548-49 (explaining that England moved away from qui tam enforcement of penal statutes in the nineteenth century as public law enforcement institutions developed); Martin H. Redish, Class Actions and the Democratic Difficulty: Rethinking the Intersection of Private Litigation and Public Goals, 2003 U. Chi. Legal F. 71,108 (noting that only in "rare cases" has the government employed a "'bounty hunter' model, by providing non-compensatory reward to private individuals to encourage them to assist in enforcing legal regulation of behavior deemed harmful to the public interest").

115. See 15 U.S.C. $\$ 15$ (a) (2006) (detailing private right under Clayton Act); 31 U.S.C. $\$ 3730$ (2000) (same for False Claims Act); 33 U.S.C. $\$ 1365$ (2000) (same for Clean Water Act); 42 U.S.C. $\$ 7604$ (2000) (same for Clean Air Act). For a flavor of the controversy surrounding these situations, see, respectively, Edward T. Swaine, The Local Law of Global Antitrust, 43 Wm. \& Mary L. Rev. 627, 661 n.125 (2001); Frank LaSalle, The Civil False Claims Act: The Need for a Heightened Burden of Proof as a Prerequisite for Forfeiture, 28 Akron L. Rev. 497, 504 n.47 (1995); Carl E. Koller Lucio, The Regulation of Hazardous Substances in Mexican Law, 5 Duke Envtl. L. \& Pol'y F. 95, 115 n.126 (1995).

116. See supra note 98 and accompanying text. 
forcement and increasing the magnitude of the sanction imposed on those against whom enforcement proceedings are brought. "A social savings in enforcement effort can be achieved by allowing sanctions to be imposed only with a low probability; and sanctions can be raised to avoid dilution of deterrence from the low probability of sanctions." 117

In a regime of profit-driven private enforcement, however, not only is such a cost-savings approach impossible, it also will be extremely difficult to reach an enforcement equilibrium-and hence a state of optimal deterrence. This is because, unlike with public enforcement, the magnitude of the sanction and the amount spent on enforcement cannot be set independently; rather "the level of the defendant's liability determines the extent of enforcement (whether a suit will be brought and how much will be spent by the parties on litigation)." 118 Thus, the higher the sanction, "the higher the payoff from suit; the higher the payoff, the more people will spend investigating and bringing suits." 119 This incentive structure, in turn, leads to excessive enforcement and, as a predictable result, overdeterrence. ${ }^{120}$

Decoupling the sanction imposed against the wrongdoer from the bounty paid to the private enforcer is one solution to this quandary. ${ }^{121}$ It has been argued that the law effectively achieves such a decoupling in class litigation, by virtue of the fact that the plaintiffs' lawyer-the true "enforcer" in small claims class actions-typically receives only a percent-

117. Shavell, supra note 98 , at 484 . For example, the public enforcer could reduce the probability of enforcement in the example in note 98 , supra, to $25 \%$, in which case we would multiply the harm of 100 by $1 / .25=4$, for a sanction of 400 (and an expected sanction of 100). Id. at 483 . If taken to an extreme, however, this approach may raise fairness concerns. Id. at 483-84.

118. A. Mitchell Polinsky, An Introduction to Law and Economics 146 (3d ed. 2003).

119. Easterbrook \& Fischel, Optimal Damages, supra note 47, at 621 ; see also William M. Landes \& Richard A. Posner, The Private Enforcement of Law, 4 J. Legal Stud. 1, 32 (1975) (" $[\mathrm{I}] \mathrm{n}$ a case where substantial resources are necessary to generate a substantial probability of apprehension, those resources can be saved by setting a very high [fine], but the high [fine] induces private enforcers to expend resources on apprehension-the resources that the high [fine] was intended to conserve.").

120. "Overdeterrence depends on the probability that an individual attaches to a future scenario in which he suffers harm from overenforcement. Overenforcement accordingly translates into overdeterrence only to the extent that individuals take it into account ex ante." Richard A. Bierschbach \& Alex Stein, Overenforcement, 93 Geo. L.J. 1743,1745 (2005) (citation and emphasis omitted). This problem does not arise when the probability of enforcement is unity, because in that case:

[T] he optimum fine would be equal to the social costs of illegal activity, and if those costs rose the optimum fine would rise by the same amount. This would be (properly) perceived by [private] enforcers as an upward shift in the demand curve facing them, and would have the effect of increasing the resources devoted to [enforcement]. But when the probability of [enforcement] is less than one, the optimum fine is higher than the social costs of the illegal activity not as a signal that additional resources should be devoted to preventing the activity, but as a means of minimizing those resources.

Posner, Economic Analysis, supra note 100, at 660 .

121. Posner, Economic Analysis, supra note 100, at 660-61. 
age of the total damages paid by the defendant in the form of a contingency fee. ${ }^{122}$ But the contingency fee increases, at least to an extent, in proportion to the size of the damages award, so the decoupling is incomplete and the basic problem may persist (albeit on a smaller scale).$^{123}$

Moreover, decoupling is not a perfect solution. Separating the bounty paid to the enforcer from the sanction paid by the defendant creates opportunities for collusion, given that the enforcer and the defendant would both be better off if they negotiated a settlement that is less than the expected sanction but greater than the expected bounty. ${ }^{124} \mathrm{Col}-$ lusive settlements are thought to be one of the most intractable agency costs associated with small claims class actions; by fostering the perception that "the private watchdog can be bought off," collusive settlements frustrate the ability of private enforcement to approximate optimal deterrence. ${ }^{125}$ The risk of collusive settlements cannot be eliminated by perfectly aligning the interests of class members and class counsel, as has been suggested in the agency costs literature, without essentially recoupling the bounty and the sanction-and thus reintroducing the problem of overenforcement.

At best, the contingency fee is a very rough approximation of the appropriate bounty. It is difficult to estimate the appropriate enforcement level even when there is a monopolistic public enforcer. Ambiguities abound as to the net social costs imposed by the misconduct, as well as the level of violations. Moreover, potential offenders may have imperfect perceptions of both the magnitude and probability of the sanction, and may not always act rationally. ${ }^{126}$ Private enforcement adds another layer for possible error by requiring that the law also estimate the bounty required to induce the desired rate of enforcement. In the context of securities fraud, for example, the system of rewards should induce private enforcers "to expend resources finding and prosecuting violations until, at the margin, the last dollar of resources spent on enforcement reduces the social costs of nondisclosure by just one dollar"-something that "is almost impossible to achieve."127

2. The Inflexibility Problem. - The difficulties associated with calculating the optimal level of deterrence highlight what is perhaps the more salient disadvantage of private enforcement. In reality, a deterrence re-

122. Coffee, Rescuing, supra note 67, at 220 n.14; Coffee, Plaintiff's Attorney, supra note 69 , at $694-95$.

123. For background on the appointment of counsel and award of fees in class actions brought under Federal Rule of Civil Procedure 23, see 5-23 James Wm. Moore et al., Moore's Federal Practice-Civil II $123.120-23.125$ (3d ed. 2008).

124. Posner, Economic Analysis, supra note 100, at 660-61.

125. Coffee, Rescuing, supra note 67 , at 226. Of course, collusion and other abuses are possible in public enforcement, as well. See Shavell, supra note 98, at 580 n.4 (observing that public enforcement agent might attempt to extort money from suspect in exchange for not turning him in); see also infra Part II.B.3.

126. Shavell, supra note 98 , at 481 .

127. Easterbrook \& Fischel, Optimal Damages, supra note 47 , at 620 . 
gime is constructed based on incomplete information and must be guided to some degree by intuition. Miscalculations will therefore be made, and adjustments will inevitably be necessary as additional information comes to light. In addition, changing circumstances will necessitate adjustment. It may be harder to make these adjustments in a regime of private enforcement. ${ }^{128}$

If overdeterrence appears to be a problem, for example, the public enforcer can adjust by ratcheting down the enforcement level; conversely, if underdeterrence appears to be a problem, the public enforcer can ratchet it up. With private enforcement, by contrast, adjustment of the enforcement level would require altering the incentives held out to private enforcers-i.e., alteration of the sanction (or, in lawyer-driven litigation, the law governing the award of attorneys' fees). This may be considerably more difficult to accomplish, at least in time to respond effectively to changed circumstances. ${ }^{129}$

Another way in which a public enforcer may adjust the deterrence calculus is through alteration of its enforcement priorities. Laws are often overbroad, meaning that they capture within their literal terms conduct that, under a more perfectly tailored rule, society would choose not to sanction or prohibit. If such a law were enforced to its letter, the threat of liability would result in overdeterrence. A public enforcer can minimize this risk through credible use of "discretionary nonenforcement"130 - that is, the public enforcer can signal that it will not enforce the sanction against those who violate the prohibition in letter but not in spirit. Discretionary nonenforcement allows society to avoid the costs of crafting more precisely tailored rules, and the loopholes such rules inevitably create. ${ }^{131}$ It also allows for ready adjustment by a public enforcer if beliefs change as to the type of conduct that warrants sanction. In a regime of unconstrained private enforcement, however, discretionary nonenforcement is a non sequitur: If there is a violation of the rule and a reward worth the cost of pursuit, the case will be brought. ${ }^{132}$

128. See Stephenson, supra note 54, at 139 (noting "difficulty in predicting ex ante the overall effect of private citizen suits and the likelihood that relevant factual or political conditions will vary over time").

129. While "private enforcement may be able to mobilize and reallocate its resources more quickly than the public enforcer, who is confined within a bureaucratic setting," Coffee, Rescuing, supra note 67 , at 226 , it will not do so absent economic motivation.

130. Landes \& Posner, supra note 119, at 38.

131. See Beck, supra note 53, at 627 ("The legislature cannot anticipate or express with precision all of the circumstances that might warrant an exception to a rule of general application, so it paints with a broader brush than the public interest requires."); Landes \& Posner, supra note 119 , at 38 " "The costs of precisely tailoring a rule to the conduct intended to be forbidden would be prohibitive given the limitations of human foresight and the inherent ambiguities of human language.").

132. See William E. Kovacic, Private Monitoring and Antitrust Enforcement: Paying Informants to Reveal Cartels, 69 Geo. Wash. L. Rev. 766, 781 (2001) [hereinafter Kovacic, Private Monitoring] ("Robust private participation, especially independent rights of action that eliminate a public prosecutorial monopoly, reduce or eliminate the ability of 
Relatedly, a public enforcer can adjust the deterrence calculus by adjusting its style of enforcement, taking less of a coercive approach and more of a cooperative approach (or vice versa) if circumstances suggest it would lead to greater compliance. "The former approach is primarily concerned with detecting offenses and punishing violators-a legalistic, by-the-book approach that relies on formal legal process," whereas "[ $t]$ he latter approach is primarily concerned with preventing violations and remedying underlying problems in a cooperative way, relying on the shadow of the law to induce that cooperation." 133 Private enforcement, however, is antithetical to a cooperative approach to regulation, for the obvious reason that private enforcers have little incentive to be cooperative. Private enforcement may therefore "engender an overemphasis on coercion and deterrence at the expense of negotiation and cooperation, regardless of the wishes of the government enforcement agency" and "may impede government efforts to persuade industries to regulate themselves, since industry-generated guidelines may subsequently become the basis for private enforcement suits." 134 In short, it "can collide with agencies' attempts to foster legitimate cooperation with regulatees." 135

\section{B. The Relative Effectiveness of Public Versus Private Enforcement of Rule $10 b-5$}

The foregoing discussion would appear to support a preference for exclusive Commission enforcement of Rule $10 \mathrm{~b}-5$ to avoid the problems that inhere in private enforcement. But that preference rests on four key assumptions that must be identified and tested in the specific Rule $10 \mathrm{~b}-5$ context before any final conclusions can be reached. The efficacy of private law enforcement cannot properly be evaluated at a transsubstantive

government enforcement officials to use prosecutorial discretion as a nonlegislative tool for altering the law."); Landes \& Posner, supra note 119, at 39 ("The existence of a public monopoly of enforcement in a particular area of the law is a necessary . . condition of discretionary non-enforcement.").

133. Joel P. Trachtman \& Philip M. Moremen, Costs and Benefits of Private Participation in WTO Dispute Settlement: Whose Right Is It Anyway?, 44 Harv. Int'l L.J. 221, 235-36 (2003); see also Jeannette L. Austin, The Rise of Citizen-Suit Enforcement in Environmental Law: Reconciling Private and Public Attorneys General, 81 Nw. U. L. Rev. 220, 257-59 (1987) (comparing and contrasting adversarial and cooperative styles of regulatory enforcement); Zinn, supra note 57 , at 87-89 (same).

134. Stephenson, supra note 54, at 118 .

135. Zinn, supra note 57, at 140 . Private enforcement may also stymie the government's efforts to send clear signals. "Levels of [public and private] enforcement may vary, carrying conflicting messages about the appropriate standard of conduct or the degree of corporate compliance." Fisch, supra note 54, at 199. It may also interfere with the government's efforts to control the development of the law. See Bucy, supra note 27, at 66-67 (observing that private enforcement "can interfere with regulatory efforts . . by generating harmful precedent that applies to public regulators"); Stephenson, supra note 54 , at 119 ("[J] udicial decisions rendered in citizen suits, brought piecemeal before nonexpert courts by citizen groups with particularized interests, may establish adverse or inconsistent precedents that complicate or disrupt government enforcement efforts."). 
level. To the contrary, "[t]he desirability of private enforcement in a particular policy area will depend on context-specific information about the regulatory problem, the characteristics of the potential private plaintiffs, and the effect of private enforcement on public enforcement efforts." 136 For this reason, recent attempts to defend the desirability of deterrenceoriented small claims class actions paint with too broad a brush. ${ }^{137}$

The four critical assumptions underlying a preference for exclusive public enforcement are: (1) that overdeterrence is a risk, (2) that the would-be private enforcers are profit driven, (3) that the public enforcer's interests are better aligned with the public's interests than the private enforcer's, and (4) that private enforcers do not otherwise enjoy some advantage that tips the scales in favor of private enforcement. As explained below, the first two assumptions are likely valid in the Rule $10 \mathrm{~b}-5$ context. Reasonable persons may differ, however, as to whether the third assumption is valid; one's view will depend on the faith one places in the Commission, relative to the plaintiffs' securities bar, to act in society's best interest. With respect to the fourth assumption, the resources of the plaintiffs' securities bar, given actual or potential budgetary constraints on the Commission, weigh in favor of private enforcement; whether they tip the scales in favor of private enforcement, however, is unclear.

1. Is Overdeterrence a Risk? - The first key assumption underlying the preference for monopolistic public enforcement is that the optimal level of deterrence is less than the maximum level of deterrence. Were it otherwise, concerns about excessive enforcement by private plaintiffs, and the overdeterrence that results, would largely disappear; the law would be "designed to deter unconditionally-not to force the firm to compare costs and benefits, but to channel its conduct into approved forms." 138

136. Stephenson, supra note 54 , at 121 ; see also Shavell, supra note 98 , at 578 ("Whether it is advantageous for legal intervention to come about through legal actions brought by private parties or through efforts of public enforcement agents depends on which method most economically results in the identification and, if necessary, the apprehension, of the parties to whom the law should apply."); Kovacic, Private Monitoring, supra note 132, at 782 ("Decisions about how to expand private participation in implementing the law require an assessment of the quality of existing enforcement institutions, including the capability, intentions, and motivations of public prosecutors.").

137. Articles in this genre include Gilles \& Friedman, supra note 70; Rubenstein, Litigation, supra note 70; Stempel, supra note 56 . For articles broadly critical of deterrence-oriented small claims class actions, see John Beisner, Class Action "Cops": Public Servants or Private Entrepreneurs?, 57 Stan. L. Rev. 1441 (2005) (cataloguing perceived vices of class action device, and recommending that class action lawyers who claim to be fulfilling public interest be held to same ethical standards as public servants); Samuel M. Hill, Small Claimant Class Actions: Deterrence and Due Process Examined, 19 Am. J. Trial Advoc. 147 (1995) (assessing problems particular to small claims class actions, and concluding that small stakes plaintiffs should be forbidden as class representatives); Redish, supra note 114, at 73 (arguing that "the modern class action has undermined the foundational precepts of American democracy").

138. Easterbrook \& Fischel, Optimal Damages, supra note 47, at 621-22. 
Discretionary nonenforcement and cooperation with potential violators would be unnecessary-indeed, inappropriate.

This assumption appears valid in the context of Rule $10 \mathrm{~b}-5$. Congress delegated to the Commission the task of setting securities fraud enforcement policy in section $10(\mathrm{~b})$ because it recognized the limitations of a fixed rule of law to govern the dynamic capital markets, and the greater institutional competence of an expert agency to respond flexibly to changed circumstances. ${ }^{139}$ The Commission, in turn, promulgated Rule $10 \mathrm{~b}-5$, which itself is "as broad as almost any statute, a sort of longarm provision in which the SEC forbids everything the statute gives it power to forbid." 140 It captures in its web a substantial amount of conduct that, under a more perfectly tailored rule, society would choose not to outlaw.

For example, by imposing what amounts to strict enterprise liability, Rule $10 \mathrm{~b}-5$ seeks to prompt the corporation to take adequate precautions to ensure that its officers do not engage in fraud. ${ }^{141}$ But the rule necessarily also captures cases where a corporation has taken appropriate care. After all, a corporation's failure to prevent a Rule $10 \mathrm{~b}-5$ violation may or may not, in a particular case, be the result of negligent oversight. Indeed, it may be extremely difficult for a board of directors to detect or prevent

139. Thel, supra note 23, at 459-60 (noting extensive delegation to Commission officials, and that "Congress gave the SEC flexibility to regulate in order that it might reshape the market in the public interest"). It is therefore not an obvious benefit that private Rule $10 \mathrm{~b}-5$ enforcement "contribute[s] to a consistent level of enforcement, recognizing that the SEC's enforcement policies vary according to administration priorities at any given time." Alexander, Rethinking Damages, supra note 45, at 1516; see Stephenson, supra note 54, at 142 (noting the value of flexibility "given the considerable uncertainty about the effects of different private enforcement schemes, the possibility of fairly rapid changes in underlying circumstances, and the fluidity of policy preferences regarding the rigor of enforcement of various statutes"); see also NYCEDC, supra note 93, at 74-75 (observing that private enforcement itself fluctuates depending on volatility of stock prices). Moreover, the observation that "private enforcement . . . [prevents] abrupt transitions in enforcement policy that have not been sanctioned by the legislature," Coffee, Rescuing, supra note 67 , at 227 , is inapposite in the securities context, because Congress sanctioned the Commission to exercise its broad discretion in setting enforcement policy. Cf. Grundfest, Rights of Action, supra note 30, at 1019 ("In the sixty years since the Commission was created, Congress has repeatedly demonstrated its inability to resolve significant policy issues related to securities fraud litigation.").

140. Thel, supra note 23 , at 463 (footnote omitted).

141. These may include the "selection of managers, design of incentives, internal controls, etc." Langevoort, Leaving Executives Naked, supra note 43, at 635; see also Cox, Making Class Actions Virtuous, supra note 56, at 511 ("Entity liability provides incentives for owners to employ efficient strategies to reduce costly violations of the law."). In light of the significant market penalty that is imposed on a company if financial fraud is detected, it is unclear whether enterprise liability is necessary as a means of prompting investment in precautions. See Karpoff, et al., Cooking the Books, supra note 48, at 1 (" $[\mathrm{T}]$ he largest monetary penalties are not imposed by regulators or courts. Rather, they are imposed by the market."). 
an officer's fraud, ${ }^{142}$ and the threat of massive class damages may prompt an unreasonably large investment in precautions that, at the end of the day, costs society more than it saves. ${ }^{143}$ Similarly, ambiguities in the legal standard mean that corporate officers may find it difficult to comply despite the best of intentions. ${ }^{144}$ The threat of liability may cause them to omit to disclose information that would benefit society (for fear that its disclosure will be deemed materially misleading), or to disclose information that costs more to produce than it is worth (for fear that its omission will be deemed materially misleading). ${ }^{145}$ In any event, they may spend too much time and too many resources trying to figure out what to do. ${ }^{146}$

142. Professors Arlen and Carney have postulated that fraud-on-the-market is most often a consequence of "last period" agency costs. See Arlen \& Carney, Vicarious Liability, supra note 41 , at 701-03. They contend that under normal conditions, officers have strong incentives to act honestly; when, however, officers fear that the corporation is facing insolvency, they may withhold disclosure of the bad news in order to buy time to turn the situation around. See id. Professor Langevoort has alternatively argued that fraud-on-themarket may be largely attributable to "corporate cultural biases," particularly optimistic ones, that lead officers to filter out or underestimate the seriousness of bad news. Langevoort, Capping Damages, supra note 40, at 655-56; Donald C. Langevoort, Organized Illusions: A Behavioral Theory of Why Corporations Mislead Stock Market Investors (and Cause Other Social Harms), in Behavioral Law \& Economics 144, 144-67 (Cass R. Sunstein ed., 2000). Both phenomena may lead to actionable misstatements or omissions under Rule 10b-5, as much as an officer's base desire to line his or her own pockets. See Pritchard, Markets as Monitors, supra note 41, at 930-37 (explaining that fraud-on-the-market is attributable to three "human frailties": fear, greed, and pollyannaism).

143. See Langevoort, Capping Damages, supra note 40, at 657 (“[W]e want firms as a whole to adopt precautionary procedures up to a point where the investment exceeds the net social cost threatened by the fraud adjusted to reflect the less-than-perfect rate of detection and enforcement.").

144. Pritchard, Markets as Monitors, supra note 41, at 936-37.

145. See Ribstein, supra note 92, at 146 ("[I]nsiders are particularly vulnerable to litigation risk since, even if the corporation or insurance pays the judgment, the insiders have a non-diversifiable risk of reputation loss.").

146. As Professors Easterbrook \& Fischel observe:

"Truth," like all good things, is costly to produce. The person selling securities must investigate the business venture at hand and package the information in a form that investors can understand. The process of acquiring and packaging information can be exceptionally expensive. Whole industries-accounting, investment banking, much of the bar, much of the financial press-are the embodiments of the costs of investigation and certification of information about firms and their securities. For any complex business, it is impossible to find and present "everything material" in a space less than that of a decent-sized library.

Easterbrook \& Fischel, Optimal Damages, supra note 47, at 615. Professor Alexander adds that:

The costs of taking care might include the measures the firm must take to discover and disclose information and to avoid misleading the public, the competitive disadvantage of making corporate information public, the risk that the firm will become overly cautious in providing information to investors or in conducting its business, and the possibility that firms will be reluctant to use the public equity markets at all. 
Whereas the Commission might exercise its discretion and choose not to sanction a corporation for its agent's violation when it has taken appropriate care, or when the challenged disclosure or omission presents a close question on liability, private enforcers lack the incentive to exercise similar restraint. ${ }^{147}$ The Commission might also exercise discretion in choosing which sanction to apply. It may impose any of a host of penalties (monetary and otherwise) that it deems appropriate in light of the specific misconduct at issue and the particular defendant's culpability and circumstances. ${ }^{148}$ Indeed, Congress expanded the Commission's enforcement arsenal in the Securities Enforcement and Penny Stock Reform Act of 1990 precisely "to introduce greater flexibility into the SEC's enforcement program with the objective of allowing the SEC 'to achieve the appropriate level of deterrence in each case and thereby maximize the remedial effects of its enforcement actions. "149

Before deciding whether to impose penalties on a corporate issuer, for example, the Commission has explained that it will consider the following nuanced factors:

- the presence or absence of a direct benefit to the corporation as a result of the violation;

- the degree to which the penalty will recompense or further harm the injured shareholders;

- the need to deter the particular type of offense;

- the extent of the injury to innocent parties;

- whether complicity in the violation is widespread throughout the corporation;

- the level of intent on the part of the perpetrators;

Alexander, Rethinking Damages, supra note 45, at 1499-1500 (footnote omitted). "Whether investors benefit by more information depends on whether the marginal benefits of increments to knowledge exceed the marginal costs." Easterbrook \& Fischel, Mandatory Disclosure, supra note 65, at 696.

147. In addition, "any enforcement system mistakenly treats some nonviolators as violators and subjects them to sanctions. The possibility of mistaken sanctions creates an error cost-the deterrence of useful conduct by the risk of liability." Frankel, supra note 52, at 573. As Professor Schwartz has noted:

Error creates the possibility that innocent conduct will be held to violate the law and guilty conduct will be exonerated. As a result, undesirable conduct becomes less costly and desirable conduct more costly. Consequently, the incentive structure generated by the system is impaired when persons subject to it anticipate the possibility of erroneous decisions.

Warren F. Schwartz, An Overview of the Economics of Antitrust Enforcement, 68 Geo. L.J. 1075,1077 (1979). This Article avoids wading into the debate over whether the "merits matter" in Rule $10 \mathrm{~b}-5$ class actions, but to the extent that they matter less than they would in a regime of monopolistic Commission enforcement, it would further support a preference for public enforcement. See Pritchard, Markets as Monitors, supra note 41, 955 ("If both weak and strong cases lead to settlements, and if the settlements are not substantially greater in strong cases, the deterrent effect of class actions is diluted.").

148. See supra note 36 and accompanying text.

149. Cox \& Thomas, SEC Enforcement Heuristics, supra note 36, at 747 (quoting H.R. Rep. No. 101-616, at 13 (1990)). 
- the degree of difficulty in detecting the particular type of offense;

- the presence or lack of remedial steps by the corporation;

- and the extent of cooperation with the Commission and other law enforcement. ${ }^{150}$

Private enforcers, by contrast, have only the blunderbuss remedy of out-of-pocket damages in their toolkit.

Past securities litigation reform efforts, as well as contemporary reform proposals calling for the elimination of enterprise liability, can be understood as responding to the risk of overdeterrence posed by Rule $10 \mathrm{~b}-5$ due to its overbreadth. The PSLRA, for example, need not be viewed as reacting simply to the prevalence (real or imagined) of nonmeritorious securities fraud strike suits. By restricting the scope of Rule 10b-5 liability (via the safe harbor for forward-looking statements) and making it more difficult to prove a violation (via the heightened pleading requirements and discovery stay), the PSLRA might also be viewed as an attempt to cut off suits which could indeed have technical "merit" under the broad reach of Rule 10b-5, but, if allowed to proceed, risk inducing an excessive investment in precautions. ${ }^{151}$ Central Bank can be similarly viewed. The Court explained that reading Section $10(\mathrm{~b})$ broadly to create secondary liability for aiders and abettors would exact "costs that may disserve the goals of fair dealing and efficiency in the securities markets." 152 The Court therefore declined to find such liability, based in part on a concern about strike suits, but based also on the fact that "the rules for determining aiding and abetting liability are unclear, in 'an area that

150. Press Release, U.S. SEC, Statement of the Securities and Exchange Commission Concerning Financial Penalties (Jan. 4, 2006), available at http://www.sec.gov/news/ press/2006-4.htm (on file with the Columbia Law Review). A new policy requires Commission staffers to receive approval by the full Commission before negotiating penalties, which may lead to greater uniformity and predictability. Christopher Cox, Chairman, U.S. SEC, Address to the Mutual Fund Directors Forum Seventh Annual Policy Conference (Apr. 13, 2007), available at http://www.sec.gov/news/speech/2007/ spch041207cc.htm (on file with the Columbia Law Review) ("[W]here the need for national consistency is greatest, we're reviving what had been a long standing policy of the SEC for all cases for many years-that Commission approval be obtained before settlement discussions are commenced.").

151. See Bierschbach \& Stein, supra note 120 , at 1758 (theorizing that "the legal system does its second-best by mitigating unavoidable overenforcement with heightened evidentiary or procedural requirements that minimize overdeterrence"); Landes \& Posner, supra note 119, at 40 ("An alternative to discretionary nonenforcement is to permit unlimited private enforcement but rewrite the substantive rules of law to eliminate overinclusion."); Stephenson, supra note 54, at 116-17 ("Because private citizens do not have the same incentives to exercise discretion in deciding which violations of the law are worth prosecuting, allowing private suits forces the government either to tolerate excessive enforcement of an overbroad rule or to narrow the rule in a way that allows many socially undesirable activities to escape regulation." (footnote omitted)); see also Mahoney, supra note 38 , at 650 (advocating adoption of heightened intent standard in Rule $10 \mathrm{~b}-5$ cases as a means of protecting against overdeterrence).

152. Cent. Bank of Denver, N.A. v. First Interstate Bank of Denver, N.A., 511 U.S. 164, 188 (1994). 
demands certainty and predictability." "153 Uncertain risk of liability might cause securities professionals to refuse to provide services to some companies altogether, the Court explained, and might cause them to increase the prices charged to others-prices "in turn [paid] by [an affected] company's investors, the intended beneficiaries of the statute." In other words, it might overdeter. ${ }^{154}$ In Stoneridge, the Court again echoed these concerns, and observed that a broad reading of the implied right might shift securities offerings away from domestic capital markets. ${ }^{155}$

The specter of private Rule $10 \mathrm{~b}-5$ enforcement also might frustrate the Commission's ability to pursue a cooperative approach to regulation. If it is to do more good than harm, Rule $10 \mathrm{~b}-5$ should encourage firms to adopt cost-effective internal controls to prevent fraud by their agents and should encourage well-intentioned officers to make cost-effective disclosure calls. Cooperation with firms, rather than heavy-handed and overly technical enforcement, may be the best way to achieve this-enforcement flexibility, at a minimum, is likely necessary. This was the view at the time of the 1934 Act's enactment. Section 10 (b) received little criticism despite its extremely broad delegation of authority to the Commission precisely because " $[\mathrm{m}]$ any securities industry witnesses were particularly critical of rigid statutory regulation" and "business leaders generally favored cooperation between industry and government." 156 But the threat of follow-on class litigation may discourage companies from coming forward to

153. Id.

154. Id. at 189. A similar sentiment motivated the Court's recent decision in Credit Suisse Securities (USA) $L L C$ v. Billing, holding that the securities laws preclude the application of antitrust laws to allegations of misconduct in the IPO underwriting process at issue in that case. $127 \mathrm{~S}$. Ct. 2383, 2387 (2007). The Court took as a given that the conduct alleged had been disapproved by the Commission, but nonetheless observed that serious harm could come of subjecting that conduct to private attack under the antitrust laws. The Court explained that "only a fine, complex, detailed line separates activity" that the Commission permits and forbids, and that "[i]n light of the nuanced nature of the evidentiary evaluations necessary to separate the permissible from the impermissible, it will prove difficult for . . . different courts to reach consistent results." Id. at 2394-95. Thus, allowing private antitrust suits to proceed would likely "overly deter syndicate practices important in the marketing of new issues." Id. at 2397. The Court further noted that the Commission might in the future decide, in its expert judgment, to alter the line between what is permissible and what is impermissible; allowing private enforcement under the antitrust laws would "threaten to disrupt the full range of the Commission's ability to exercise its regulatory authority." Id. at 2396 (citation omitted).

155. Stoneridge Inv. Partners, LLC v. Scientific-Atlanta, Inc., 128 S. Ct. 761, 772 (2008).

156. Thel, supra note 23 , at 441 . The Commission recently expressed a similar sentiment, noting that "the SEC's first Chairman described the SEC's role and our relationship to business as a partnership." Review of Investor Protection and Market Oversight with the Five Commissioners of the Securities and Exchange Commission: Hearing Before the H. Comm. on Financial Servs., 110th Cong. 11 (2007), available at http://frwebgate.access.gpo.gov/cgi-bin/getdoc.cgi?dbname=110_house_hearings\&docid =f:37560.wais.pdf (on file with the Columbia Law Review) [hereinafter SEC Investor Protection Hearing Statement] (statement of Christopher Cox, Chairman, United States Securities and Exchange Commission). 
the Commission when violations have occurred in order to seek a cooperative solution, since the class action "compensatory paradigm does not allow for damages reductions to encourage monitoring and reporting." 157 Moreover, "the voluntary disclosure of otherwise privileged information in securities enforcement matters may constitute waiver of the work product doctrine and attorney-client privilege" in subsequent class litigation. ${ }^{158}$

2. Are Private Enforcers Profit Driven? - Another key assumption underlying the preference for public enforcement is that private enforcers are motivated to prosecute claims primarily by the prospect of monetary

157. Pritchard, Markets as Monitors, supra note 41, at 993-94. Professor Arlen has argued that enterprise liability is justified only insofar as it induces corporations to adopt policing mechanisms that increase the probability that fraud is detected and individual wrongdoers are sanctioned-something it cannot do effectively if there is unrestricted private enforcement. Jennifer Arlen, Public Versus Private Enforcement of Securities Fraud 46 (2007) (unpublished manuscript, on file with the Columbia Law Review) [hereinafter Arlen, Public Versus Private] ("Public enforcers cannot threaten a firm with sufficient liability to induce reporting . . . if it faces ruinous liability even if it does report, especially since reporting guarantees the imposition of such a sanction."); see also Booth, supra note 95 , at 31 (" $[I] \mathrm{t}$ is not too strong to say that the current system of enforcement by the [securities fraud class action] effectively precludes any effective form of selfpolicing.").

158. Kenneth B. Winer, Introduction to 1 Securities Enforcement: Counseling and Defense, supra note $36, \S \S 1,1.02$. Fear of even greater open-ended private liability may have dampened corporate interest in a more "principles-based" approach to securities regulation, despite criticisms that an overemphasis on coercion by U.S. regulators has placed the U.S. securities markets at a competitive disadvantage vis-à-vis the United Kingdom. See NYCEDC, supra note 93, at 82-85 (discussing criticisms of U.S. enforcement system relative to United Kingdom's); see also Zingales et al., Interim Report, supra note 96, at 9 (noting benefits of "more prudential regulation," including "greater willingness of securities firms to step forward with self-identified problems, earlier identification and better understanding by regulators of high-risk issues, and generally greater cooperation between the regulators and the regulated"); Coffee, Law and the Market, supra note 7, at 272 (observing that "[b]y style and temperament, the United States punishes more severely" than the United Kingdom); James D. Cox \& Edward F. Greene, Financial Regulation in a Global Market Place: Report of the Duke Global Capital Markets Roundtable, 18 Duke J. Comp. \& Int'l L. 239, 244 (2007) (discussing benefits of principles-based regulation but noting that "the prevalence of private litigation for disclosure violations likely calls for greater clarity in disclosure requirements, such that a rules-oriented approach to disclosure is appropriate"). Some have suggested that it would be desirable for the SEC to adopt a principles-based regulatory approach, following the example of the Commodities Futures Trading Commission (CFTC). See, e.g., Zingales et al., Interim Report, supra note 96, at 64. More recently, the Treasury Department released a report recommending that the functions of the SEC and CFTC be merged, along with the two agencies' "regulatory philosophies"; the report notes that implied private rights of action are more prevalent under the securities laws than under the Commodity Exchange Act and suggests that these varied approaches be "harmonized," though it stops short of expressly articulating a preference for one over the other. The Department of the Treasury Blueprint for a Modernized Financial Regulatory Structure 115-88 (2008), available at http://www.treas.gov/press/releases/reports/Blueprint.pdf (on file with the Columbia Law Review). 
reward. ${ }^{159}$ If, instead, the private enforcers' motivations more naturally aligned with the public's (i.e., to achieve optimal deterrence), it would be possible to keep the magnitude of the sanction independent from its probability and thus to avoid excessive enforcement. Stated another way, non-profit-driven private enforcers might in fact be motivated to engage in a form of discretionary nonenforcement. ${ }^{160}$

The assumption that private enforcers are motivated by profit appears valid in the context of Rule 10b-5. The "conventional wisdom has long been that companies with small market capitalizations are less likely to be sued in securities class actions." 161 Moreover, empirical studies demonstrate that historically Rule $10 \mathrm{~b}-5$ class actions have targeted companies with larger market capitalizations than the Commission targets. ${ }^{162}$ The larger a company's market capitalization, "the larger the losses suffered by the putative class, and the larger the potential settlement fund"-and contingency fee. ${ }^{163}$

This dynamic highlights a fundamental difference between private Rule 10b-5 enforcement and, for example, private enforcement of the environmental or civil rights laws. In the latter cases, the private enforcers may be incentivized to bring suit based on ideological beliefs. Assum-

159. See Dayna Bowen Matthew, The Moral Hazard Problem With Privatization of Public Enforcement: The Case of Pharmaceutical Fraud, 40 U. Mich. J.L. Reform 281, 332-33 (2007) ("Where large financial payoffs inure to the personal benefit of the private enforcer, there is a greater likelihood that private economic interests will lead plaintiffs to pursue claims that diverge from the public goals of a public statute.").

160. This distinction has been captured using a variety of labels-entrepreneurial/ ideological, bounty hunter/lone ranger, mercenary/social advocate. Cf. Rubenstein, Private Attorney General, supra note 58, at 2156 (outlining public/private spectrum of lawyering that takes into account the client, the fee arrangement, and the goal of the litigation).

161. Coffee, Reforming Securities Class Action, supra note 43, at 1543; see also Baker \& Griffith, supra note 23, at 503 (finding that the "amount of D\&O insurance purchased correlates with the market capitalization of the corporate buyer"); Stephen J. Choi, The Evidence on Securities Class Actions, 57 Vand. L. Rev. 1465, 1480-81 (2004) ('Plaintiffs' attorneys will not wish to file even a meritorious suit against a small market capitalization firm with low stock market turnover to the extent the potential damages from such a suit are low and thus unlikely to compensate the plaintiffs' attorney for the relatively fixed costs of litigation.").

162. See Cox \& Thomas, SEC Enforcement Heuristics, supra note 36, at 764 ("In our sample, the SEC targeted companies with an average market capitalization $\$ 735$ million less than those sued by the private plaintiffs' bar alone."). The SEC has begun to target larger companies in recent years. James D. Cox \& Randall S. Thomas, Public and Private Enforcement of the Securities Laws: Have Things Changed Since Enron?, 80 Notre Dame L. Rev. 893, 901-02 (2005) [hereinafter Cox \& Thomas, Since Enron].

163. Lisa L. Casey, Reforming Securities Class Actions from the Bench: Judging Fiduciaries and Fiduciary Judging, 2003 BYU L. Rev. 1239, 1241. The criminal indictment of Milberg Weiss on charges of paying kickbacks to clients to induce them to serve as lead plaintiffs in class action lawsuits casts further doubt on the image of the plaintiffs' securities bar as unmotivated by profit. See Ashby Jones \& Nathan Koppel, Milberg Settles with Government: Law Firm Admits It Paid Kickbacks; Fine of $\$ 75$ Million, Wall St. J., June 17, 2008, at B2. 
ing those beliefs reflect well the public sentiment regarding the optimal level of deterrence, ${ }^{164}$ private enforcement in such cases may be efficient. ${ }^{165}$ One (albeit dated) empirical study supports this distinction; it concludes, based on an evaluation of a sample of certified class actions in the Northern District of California over a five year period, that a profitdriven enforcer "is less likely to put together an innovative legal package, less likely to get a class certified, less likely to actively attempt to mobilize the class, and less likely to pursue injunctive relief, than a public interest or legal service lawyer focused on social advocacy."166

It was noted above that the PSLRA's "lead plaintiff" provision is designed to ensure that the party with the largest stake in the litigation selects and monitors class counsel, so that litigation decisions better reflect the interests of the plaintiff class (thus reducing lawyer-client agency costs). ${ }^{167}$ Alternatively, that provision may be viewed as an attempt to place institutional investors at the helm in order to make litigation decisions better reflect the public's interest in achieving optimal deterrence. Institutional investors may be less likely to be motivated by a narrow desire to profit in any particular case, at least relative to nondiversified class members and unmonitored plaintiffs' lawyers. These repeat players may be more likely to appreciate the greater economic consequences of excessive litigation on the capital markets. In short, their interests may be better aligned with the public's. ${ }^{168}$ Institutional investors acted as lead plaintiffs in less than half of Rule 10b-5 class actions in 2007, however, more than a decade after the PSLRA's enactment. ${ }^{169}$ It thus appears that, not-

164. See Austin, supra note 133, at 257 ("An environmental group's incentives to bring suit resemble the incentives of public enforcers more closely than those of private plaintiffs who can recover damages.").

165. It might also be the case that Congress intended to make a "credible commitment" when it provided for private enforcement of the environmental laws:

In order to guarantee their intentions, governments, like parties to a contract generally, may take certain steps to restrict their freedom of action or at least to impose costs on themselves for violating their commitments. Granting private rights of action could be considered such a credible commitment: by taking the decision to enforce regulations out of the hands of government officials, the government signals that the laws being enforced by private parties will not be subject to uneven discretionary enforcement.

Trachtman \& Moremen, supra note 133, at 241.

166. Garth et al., supra note 71 , at 396 . Of course, "it remains true that what galvanizes environmental advocates may not accord with the most appropriate priorities from a public standpoint." Rabkin, supra note 55, at 191.

167. See supra notes $75-76$ and accompanying text.

168. Matthew, supra note 159, at 331-32 (observing that the PSLRA's "reforms more closely align the interests of private enforcers with the public goals of protecting the integrity of U.S. capital markets").

169. There has been an increase in institutional investor involvement in securities class actions since the enactment of the Sarbanes-Oxley Act of 2002; PricewaterhouseCoopers reports that in 2006 large institutional investors acted as lead plaintiff in approximately $56 \%$ of cases, up from $22 \%$ in 2002. PWC, 2006 Study, supra note 93 , at 38 . In 2007 , however, this figure dropped to $48 \%$. PricewaterhouseCoopers 
withstanding this reform, Rule $10 \mathrm{~b}-5$ class actions will continue to be predominately profit-motivated.

3. Are Public Enforcers Better Able to Represent the Public Interest? - A third, and critical, assumption underlying the preference for monopolistic public enforcement is that the public enforcer's interests are better aligned with the public's interest in achieving optimal deterrence than are the private enforcer's. Discretionary nonenforcement is a powerful tool, and the government's use of it could conceivably result in greater deviations from optimal deterrence than even profit-driven private enforcement. ${ }^{170}$ Indeed, "allowing regulators . . . broad discretion places great faith in their ability to recognize and represent public interests,"171 and "capture can potentially result from the prosecutorial discretion that is essential to a cooperative approach to enforcement." 172 It is important to note that the inquiry here is a relative one. That private enforcement may "serve[] as a valuable check on government laxity and inefficiency" may be true, ${ }^{173}$ but it does not answer the binary question of whether private or exclusive public enforcement will better approximate optimal deterrence.

LLP, 2007 Securities Litigation Study 33 (2007), available at http://www.pwc.com/ extweb/pwcpublications.nsf/docid/71 BC6FB788E2FE8785257425006DEE88/\$file/2007_ security_litigation_study.pdf (on file with the Columbia Law Review) [hereinafter PWC, 2007 Study]. NERA reports that "[c]ases with an institutional investor acting as lead plaintiff settle for approximately one-third more on average" than cases involving other lead plaintiffs, noting that it "is impossible to judge whether this correlation reflects the actions of the lead plaintiff, or the nature of the cases in which institutions choose to be lead plaintiffs." Foster et al., supra note 48, at 9; see also James D. Cox \& Randall S. Thomas, Does the Plaintiff Matter? An Empirical Analysis of Lead Plaintiffs in Securities Class Actions, 106 Colum. L. Rev. 1587, 1589 (2006) ("[M]ore than ten years after the enactment of the lead plaintiff provision, the claim that the lead plaintiff, and particularly the lead plaintiff that is an institutional investor, is a more effective monitor of class counsel in securities fraud class actions continues to be intuitively appealing, but remains unproven."). But see James D. Cox, Randall S. Thomas \& Lynn Bai, There Are Plaintiffs and ... There Are Plaintiffs: An Empirical Analysis of Securities Class Action Settlements, 61 Vand. L. Rev. 355, 378-79 (2008) (finding that involvement of institutional investors as lead plaintiffs in securities class actions adds value to outcome); Michael A. Perino, Institutional Activism Through Litigation: An Empirical Analysis of Public Pension Fund Participation in Securities Class Actions 3 (St. John's Legal Studies Research Paper, Paper No. 06-0055, 2006), available at http://ssrn.com/abstract $=938722$ (on file with the Columbia Law Review) (describing empirical findings based on analysis of post-PSLRA settlements, which "suggest that public pension funds do act as effective monitors").

170. See Landes \& Posner, supra note 119, at 41 (noting that a "major cost of discretionary nonenforcement arises from its converse, which is selective or discriminatory enforcement").

171. Zinn, supra note 57 , at 102 .

172. Trachtman \& Moremen, supra note 133, at 240. See generally Stephenson, supra note 54, at 131 (noting that recent scholarship suggests that capture concerns are overblown and "public interest" considerations play an important role in administrative decisionmaking); Zinn, supra note 57, at 107-11 (describing classic theory of regulatory capture).

173. Fisch, supra note 54, at 199. But see Matthew, supra note 159, at 297-306 (arguing that private enforcement may have deleterious effect on public enforcement). 
Reasonable minds may differ on whether the assumption that the Commission's interests are better aligned with the public's is valid in the context of Rule 10b-5 enforcement. ${ }^{174}$ The Commission clearly is not a perfect institution. While sometimes touted as a model administrative agency, ${ }^{175}$ recently it has been criticized as being too sympathetic to corporate interests. ${ }^{176}$ The Commission is subject to political whims (particularly with respect to its budget), ${ }^{177}$ and exhibits behavioral biases. ${ }^{178}$ That said, it is probably incorrect to assert that the Commission is a "captive" of the securities industry, if for no other reason than the fractious divisions within that industry. ${ }^{179}$ A leading historian of Wall Street has observed that "the 'capture' theory and its many variants, like the agency

174. Professor Coffee has observed that "[a]lthough the public prosecutor lacks any profit motive that might lead him to bring weak or marginal cases for their nuisance value, a prosecution can be motivated by ideological, political, and careerist motives"; he views it as "an open question as to which set of perverse incentives is more dangerous." Coffee, Rescuing, supra note 67, at 227 n.25. For a somewhat different view, see Howard M. Erichson, Coattail Class Actions: Reflections on Microsoft, Tobacco, and the Mixing of Public and Private Lawyering in Mass Litigation, 34 U.C. Davis L. Rev. 1, 43 (2000), suggesting that " $[\mathrm{g}]$ iven the political checks on ... government lawyers, and given that [their] compensation is not driven by litigation outcomes to the same extent as private lawyer compensation, one would expect government lawyers to be somewhat less likely than private litigators to pursue litigation without a reasonable basis."

175. See Frank B. Cross \& Robert A. Prentice, The Economic Value of Securities Regulation, 28 Cardozo L. Rev. 333, 369 n.167 (2006) ("[The SEC] remains one of the most respected federal agencies and has for seventy years enjoyed a good reputation.").

176. See Walt Bogdanich, Senate Report Says S.E.C. Botched Hedge Fund Inquiry, N.Y. Times, Feb. 2, 2007, at C2 (discussing perception of "extraordinarily lax enforcement" efforts against prominent fund); Jesse Westbrook, Cox Sets off Alarms on Investor Rights with SEC Moves, Bloomberg.com, May 24, 2007, at http://www.bloomberg.com/apps/ news?pid=20601103\&refer=us\&sid=AEKhD.swr7bY (on file with the Columbia Law Review) (detailing concerns, following controversial SEC decisions, that Chairman Cox "is favoring corporations at the expense of investors"). The Commission recently fired back, explaining before the House Financial Services Committee that the issues it faces:

are sometimes trivialized as disputes between business and investors. The truth is, only if the business succeeds will its investors prosper. That's why the SEC's first Chairman described the SEC's role and our relationship to business as a partnership. But anyone who seeks to drive a wedge between the interests of the business and the interest of investors in that business will find themselves confronted by a relentless and powerful adversary in the [SEC].

SEC Investor Protection Hearing Statement, supra note 156, at 11; see also Kara Scannell, SEC Backs Investors on 'Scheme Liability', Wall St. J., June 4, 2007, at A5 (reporting on SEC's decision to side with plaintiffs in Stoneridge).

177. A.C. Pritchard, The SEC at 70: Time for Retirement?, 80 Notre Dame L. Rev. 1073, 1092 (2005) [hereinafter Pritchard, SEC at 70].

178. See Stephen J. Choi \& A.C. Pritchard, Behavioral Economics and the SEC, 56 Stan. L. Rev. 1, 20-36 (2003) (cataloging "a series of biases that SEC officials may face").

179. See Seligman, supra note 19, at $x i x-x x$ ("[M]uch of the power of an agency such as the SEC is derived from the divisions within the industries it regulates."); Stephenson, supra note 54, at 131 ("The risk of capture is . . less acute when an agency has a broad jurisdiction, as such agencies respond to (and draw their personnel from) multiple constituencies with competing interests."). 
'life stage' theory, are of relatively little use in explaining how any particular SEC decision actually was made." 180

Moreover, if the Commission were to perform suboptimally as a monopolistic enforcer of Rule $10 \mathrm{~b}-5$, it would be subject to political rebuke. Congress retains the ability to influence or override Commission policy with which it disagrees. ${ }^{181}$ Indeed, just recently Congress flexed its muscles by calling all five Commissioners to testify before the House Financial Services Committee to inquire about their efforts at investor protection. ${ }^{182}$ (If anything, the Commission may be too responsive to Congress.) ${ }^{183}$ The Commission's actions also remain subject to judicial review, which "may be an antidote to agency capture." 184

180. Seligman, supra note 19 , at xix.

181. The SEC differs in important respects from executive agencies:

[T] he SEC is an independent, 'legislative' agency, with the powers it exercises delegated from Congress under Article $I$ and its power flowing from its organic statutes, the 1933 and 1934 Acts. While the Chairman of the SEC is typically appointed by the then-incumbent President, he does not serve at the pleasure of the executive, nor do the other Commissioners.

Thad A. Davis, A New Model of Securities Law Enforcement, 32 Cumb. L. Rev. 69, 127 (2001); see also Joseph P. Bauer, Reflections on the Manifold Means of Enforcing the Antitrust Laws: Too Much, Too Little, or Just Right?, 16 Loy. Consumer L. Rev. 303, 321 (2004) (noting that historically bipartisan nature of antitrust enforcement "may be the product of the fact that enforcement is not solely the responsibility of the executive branch").

182. Review of Investor Protection and Market Oversight with the Five Commissioners of the Securities and Exchange Commission: Hearing Before the $\mathrm{H}$. Comm. on Financial Servs., 110th Cong. (2007), available at http://frwebgate.access.gpo.gov/cgi-bin/getdoc. cgi?dbname=110_house_hearings\&docid=f:37560. wais.pdf (on file with the Columbia Law Review); Kara Scannell, (Entire) SEC Makes House Call, Wall St. J., June 26, 2007, at C2; see also Kara Scannell, GAO Report Criticizes SEC's Probes, Settlement Distributions, Wall St. J., Sept. 14, 2007, at A10 (detailing results of congressionally commissioned review of SEC's enforcement division); Press Release, Gerald J. Guarcini \& Lisa M. Cuifolo, Ballard Spahr Andrews \& Ingersoll, LLP, Congressional Report Finds that SEC Squandered Important Insider Trading Investigation and Recommends Reforms (Aug. 15, 2007), available at http://ballardspahr.com/press/article.asp?ID=1819 (on file with the Columbia Law Review) (reporting additional congressional pressure on SEC).

183. See Pritchard, SEC at 70, supra note 177, at 1076-77 (arguing that "the SEC's status as an 'independent' agency leaves it vulnerable to the political whims of key legislators" which "fuels the cyclical pattern of neglect and hysterical overreaction that typifies securities regulation emanating from both the SEC and Congress," and suggesting "[m] oving securities regulation to the executive branch" to "help insulate the field from this destructive pattern"); cf. Radio Ass'n on Defending Airwave Rights v. U.S. Dep't of Transp., 47 F.3d 794, 808 (6th Cir. 1995) ("We believe it entirely proper for Congressional representatives to represent the interests of their constituents before administrative agencies. ... . $[\mathrm{A}]$ dministrative agencies are expected to balance Congressional pressure with the pressures emanating from all other sources." (quoting Sierra Club v. Costle, 657 F.2d 298, 409-10 (D.C. Cir. 1981))).

184. Trachtman \& Moremen, supra note 133 , at 240 ; see also Landes \& Posner, supra note 119, at 41 ("Although the danger of discriminatory enforcement is a serious one, it is somewhat mitigated by judicial doctrines that limit discretionary enforcement . . . .). 
By contrast, private enforcers are not subject to electoral discipline. And, as explained above, their profit motive is inherently misaligned with the public's interest in achieving optimal deterrence, given Rule 10b-5's substantial overbreadth. ${ }^{185}$ Correcting for this misalignment may be more difficult than-or at least as difficult as-monitoring the Commission for capture or regulatory inefficiency. ${ }^{186}$

4. Do Special Factors Weigh in Favor of Private Enforcement? - Even taking the preceding assumptions as a given in the Rule $10 \mathrm{~b}-5$ context-i.e., (1) that overdeterrence is a risk, (2) that private enforcers are profitdriven, and (3) that their interests are not as well aligned with the goal of optimal deterrence as the public enforcer's-private enforcement might still be justified if private enforcers enjoy some other advantage that tips the scales in their favor. For example, private enforcement might be justified if private parties naturally possess information about violations, information that is difficult for a public enforcer to obtain. ${ }^{187}$ In this scenario we might be more concerned about the underdeterrence that would result from monopolistic public enforcement than the overdeterrence that might result from private enforcement.

Qui tam actions brought under the False Claims Act may be defended on this basis, because a whistleblowing insider may have superior access to information than a government agency with which the company has contracted. ${ }^{188}$ Fraud-on-the-market Rule $10 \mathrm{~b}-5$ class actions, however, cannot be so readily defended on this ground. At least if followed

185. See supra Part II.A, II.B.2.

186. This seems particularly likely given the additional layer of agency costs peculiar to class litigation. See Richard A. Nagareda, Class Actions in the Administrative State: Kalven and Rosenfield Revisited, 75 U. Chi. L. Rev. 603, 642 (2008) [hereinafter Nagareda, Class Actions] (drawing parallel between principal-agent problems that attend administrative agencies and those that attend class litigation: "for administration, the concern that agencies will drift from the preferences of their legislative creators and, for class actions, the fear that lawyers will serve themselves while disserving the members of the class" (footnote omitted)). Private enforcement also raises democratic concerns. See Garth et al., supra note 71, at 395 ("[Private enforcement] can mask a tremendous increase in regulation by suggesting that enforcement is separate from other activities of governmental bureaucracies"; conversely, it can "camouflage a dramatic decrease in such regulation by suggesting that private enforcement will somehow fill the gap."); Stephenson, supra note 54, at 119 (observing that because "neither the citizens bringing private enforcement suits nor the judges who decide them are subject to electoral discipline, private enforcement may undermine a valuable democratic feature of American governance"); Stewart \& Sunstein, supra note 110 , at 1294 ("[T] he very origins of administrative agencies lay in dissatisfaction with private litigation as an undemocratic mechanism for social choice and control.").

187. Shavell, supra note 98 , at $578-80$.

188. See William E. Kovacic, Whistleblower Bounty Lawsuits as Monitoring Devices in Government Contracting, 29 Loy. L.A. L. Rev. 1799, 1821-22 (1996) [hereinafter Kovacic, Whistleblower] ("The chief efficiency advantage of qui tam bounty hunting is that it gives oversight and enforcement powers to those closest to the relevant information."); Rubenstein, Private Attorney General, supra note 58, at 2152 (noting that qui tam realtor "is authorized, in the first place, precisely because it is believed that private parties (whistle blowers) will be in a better situation to uncover fraud"). 
by a stock price drop, securities fraud "is peculiarly susceptible to ultimate detection when committed by agents of publicly held corporations," and the "identity of the wrongdoer is readily ascertainable." 189 This is because such cases "involve affirmative wrongful public acts that frequently are in writing and attributed to signatories or a named spokesperson." 190 Moreover, the Commission, as the repository for and reviewer of public company filings, stands in a better position to acquire information indicative of violations than the plaintiffs' securities bar or diffuse shareholders. Indeed, a recent empirical study examining alleged corporate frauds between 1996 and 2004 in companies with more than $\$ 750$ million in assets found that "private securit[ies] litigation play[ed] a minimal role (less than 2 percent)" in the detection of the frauds included in the sample. ${ }^{191}$ The Commission did slightly better at $6 \%$, though the highest share $(19 \%)$ was attributable to company insiders. ${ }^{192}$ Perversely, private enforcement of Rule $10 \mathrm{~b}-5$ operates to discourage this type of selfreporting. ${ }^{193}$

Another, less compelling, factor that might tip the scales in favor of private enforcement is simple resource advantage. If the public enforcer lacks adequate resources to detect and prosecute violations, even if otherwise better positioned to do so, private enforcement may be justified. Again, we might be more concerned about the underdeterrence that would result from monopolistic public enforcement in this situation than the overdeterrence that could result from private enforcement. Private enforcement of the securities laws is often defended on this basis. ${ }^{194}$ It is

189. Arlen \& Carney, Vicarious Liability, supra note 41 , at $701,710$.

190. Id. at 710 .

191. See I.J. Alexander Dyck, Adair Morse \& Luigi Zingales, Who Blows the Whistle on Corporate Fraud? 1-2 (Univ. of Chi., CRSP Working Paper No. 618, 2007), available at http://ssm.com/abstract=959410 (on file with the Columbia Law Review).

192. Id. at 2.

193. See supra note 157 and accompanying text; see also Bucy, supra note 27 , at 59-60 (explaining that class action format is "designed to discourage knowledgeable insiders from coming forward" because "[a] class member who incurred the professional and personal risks to reveal inside information regarding the wrongdoing alleged by the class would receive nothing for incurring these risks; all the whistleblower would get is a pro rata share, based upon the amount of stock held" (if the whistleblower is a class member at all)). The Sarbanes-Oxley Act of 2002 contains provisions protecting whistleblowers to encourage insiders to report fraud, but its efficacy is in doubt. See Michael Delikat, Blowing the Whistle on Sarbox, Wall St. J., Aug. 23, 2007, at A10 (suggesting that SOX's whistleblower provisions have been abused by employees with axes to grind); Dyck et al., supra note 191, at 6 (finding that "non monetary incentives for employee whistleblowers introduced by SOX do not lead to an increased rate of detection by employees" and that, in the sample examined, "employee whistleblowing drops from $20.7 \%$ to $15.6 \%$ of cases after SOX"); see also Kovacic, Private Monitoring, supra note 132, at 777-78 (describing ways law can encourage private monitoring short of granting private rights of action).

194. Langevoort, Leaving Executives Naked, supra note 43, at 654 (“[C]oncern over shortage of resources is the standard argument for supplementing SEC enforcement with private rights of action under the securities laws."). 
a rather fragile defense, to be sure: Congress could simply increase appropriations to the Commission, ${ }^{195}$ and has in fact done so in recent years. ${ }^{196}$ But, taking it as valid, it extends only so far.

If a bounty is offered to private enforcers in order to entice them to detect and prosecute those Rule $10 \mathrm{~b}-5$ violations the Commission cannot afford to, the justification for the bounty does not extend to violations that the Commission would choose not to pursue in a world of infinite resources. Nor does it extend to so-called "copycat" Rule 10b-5 class actions-i.e., class actions that allege violations that the Commission (or some other governmental agency) has already detected and prosecuted. ${ }^{197}$ In 2007 , at least $15 \%$ of securities class actions filed in federal court also involved formal or informal Commission investigations or some form of Commission action; the figure in 2006 was even higher at $32 \% .198$ Such actions would appear to result purely in the generation of transaction costs. ${ }^{199}$

It has been suggested that copycat actions do aid in deterrence because administrative penalties alone may be insufficient to adequately deter, ${ }^{200}$ or because the government takes them into account in setting penalties. ${ }^{201}$ It is true that "even in major scandals where the SEC has brought its own action, the damages paid in securities class actions are usually (but not always) a multiple of those paid to the SEC." 202 It does

195. Pritchard, Markets as Monitors, supra note 41, at 1017-18.

196. The Commission's budget jumped considerably in 2002 in the wake of Enron and related scandals, see Abigail Rayner, SEC to Get $20 \%$ Boost to Budget, Times (London), Jan. 4, 2003, at 54, but has leveled off more recently. See Sara Hansard, Some in Congress Worried About Meager Increase in SEC Proposed Budget, Investment News, May 19, 2008, at 12 (citing congressional freeze in Commission's budget in fiscal years 2006 and 2007).

197. See Coffee, Rescuing, supra note 67 , at 226 (“[W] hen the private attorney general becomes a 'free rider,' society loses the promise that . . . private resources would supplement public efforts in the detection of law violations by bringing actions that otherwise would not have been initiated."); Redish, supra note 114, at 89 ("[C] oattail class actions obviously fail to perform the classic function of privately generated exposure of unlawful behavior traditionally facilitated by the private-attorney general concept.").

198. PWC, 2007 Study, supra note 169, at 22.

199. See Bucy, supra note 27 , at 63 (observing that "[e]ven meritorious actions, if brought separately by public and private enforcers who have not coordinated their efforts, result in unnecessary costs and uncertainty for industry"). It appears that plaintiffs' lawyers have been smart to bring these suits, however. See Foster et al., supra note 48 , at 9 (finding, based on analysis of securities fraud class actions filed in first half of 2007, that cases "with any kind of official investigation, consent decree, or penalty settle for, on average, approximately $20 \%$ more than cases without any official action"); Cox \& Thomas, Since Enron, supra note 162, at 898-99 (finding, based on sample of 389 securities fraud class actions, that those "without parallel SEC actions result in lower average (median) settlements").

200. Coffee, Rescuing, supra note 67, at 224-25.

201. Gilles \& Friedman, supra note 70 , at $156-58$.

202. Coffee, Reforming Securities Class Action, supra note 43, at 1543; see also Howell E. Jackson, Variation in the Intensity of Financial Regulation: Preliminary Evidence and Potential Implications, 24 Yale J. on Reg. 253, 280 \& tbl.3 (2007) 
not logically follow, however, that the penalties imposed by the Commission are inadequate to deter, or are set intentionally low in order to account for class litigation-or, if they are, that permitting copycat class action lawsuits is more efficient than simply authorizing and imposing greater administrative penalties. ${ }^{203}$ As indicated in Part $\mathrm{I}$, the damages measure employed in Rule $10 \mathrm{~b}-5$ class actions is widely recognized as a poor proxy for the actual harm caused by securities fraud, so it makes little sense to use those damages as a benchmark. ${ }^{204}$ In addition, a bald comparison between Commission penalties and Rule 10b-5 class action recoveries fails to account for the fact that the Commission has in its enforcement arsenal non-monetary sanctions, like officer and director bars, that serve as stronger deterrence weapons vis-à-vis individual wrongdoers than class damages, which fall primarily on corporations under principles of enterprise liability. ${ }^{205}$

It should be noted, moreover, that the disgorgement and penalties imposed by the Commission have increased significantly in recent years. ${ }^{206}$ The SEC's enforcement efforts resulted in disgorgement and penalties ordered against securities law violators of roughly $\$ 500$ million in 2000 and 2001, as compared to more than $\$ 1$ billion every year since. ${ }^{207}$ To put this in perspective, the monetary sanctions imposed by the Commission dwarf those imposed by financial regulators in other jurisdictions-jurisdictions that do not have available the securities fraud class action as a supplementary enforcement device. Based on conservative estimates, Professor Coffee calculates that the SEC imposes "financial penalties that exceed those of the [United Kingdom's Financial Services Authority] by a nearly ten-to-one margin (at least in 2004 and 2005)."208 Professor Jackson has reported that, even when adjusted for market size, the United States has substantially more enforcement actions and im-

[hereinafter Jackson, Intensity of Regulation] (contrasting annualized monetary sanctions from SEC actions and private class actions).

203. But see Jonathan M. Karpoff, D. Scott Lee \& Gerald S. Martin, The Legal Penalties for Financial Misrepresentation 11, 26-27 (May 1, 2007) (unpublished manuscript, on file with the Columbia Law Review), available at http://ssm.com/abstract= 933333 [hereinafter Karpoff et al., Legal Penalties] (noting that anecdotal evidence indicates that SEC considers results of private lawsuits when establishing its penalties and finding evidence of substitution between private and public penalties, with increases in regulatory penalties crowding out use of private penalties).

204. See supra notes $99-100$ and accompanying text.

205. See supra note 101 and accompanying text.

206. See Carrie Johnson, SEC Shift May Lead to Lower Penalties, Wash. Post, Apr. 13, 2007, at D01 ("Penalties reached record proportions after destructive scandals at Enron, WorldCom and Adelphia Communications, creating concern among some commissioners that enforcement staff members are overreaching.").

207. Disgorgement and penalties totaled approximately $\$ 1.6$ billion in FY 2007, $\$ 3.3$ billion in FY 2006, $\$ 3$ billion in FY 2005, $\$ 3$ billion in FY 2004, $\$ 1.1$ billion in FY 2003, and $\$ 1.4$ billion in FY 2002. U.S. SEC, Annual Reports, available at http://sec.gov/about/ annrep.shtml (on file with the Columbia Law Review).

208. Coffee, Law and the Market, supra note 7, at 272. 
poses substantially more public monetary sanctions than either the United Kingdom or Germany-comparisons that "do not factor in private securities litigation, which accounts for more than a third of monetary sanctions imposed on U.S. securities markets and which lack any counterpart in either Britain or Germany."209

Private enforcement of Rule $10 \mathrm{~b}-5$ also has been defended on the ground that plaintiffs' securities lawyers enjoy a competitive advantage when it comes to large scale litigation, and thus "it often may be more efficient for public agencies to concentrate on detection (an area where they have the comparative advantage because of their superior investigative resources) and leave the actual litigation of the case to private enforcers." 210 This assumes, however, a level of coordination that does not exist in the current Rule 10b-5 enforcement system: Private plaintiffs can and do bring actions that the Commission would not want litigated by private enforcers, either because the Commission believes that it has already adequately penalized the defendant or because, in the exercise of its discretion, it would choose not to sanction the defendant. ${ }^{211}$ Moreover, the vast majority of Rule $10 \mathrm{~b}-5$ class actions are either disposed of on a motion to dismiss or settled prior to trial, ${ }^{212}$ so the skills necessary to litigate these actions are limited to motions briefing and, perhaps, some limited discovery-important lawyering skills, to be sure, but ones unlikely to give rise to a distinct competitive advantage.

***

Borak's mantra that private enforcement is a "necessary supplement" to Commission action merely states a conclusion, and the foregoing analysis demonstrates that it is hardly a self-evident one. To the contrary,

209. Jackson, Intensity of Regulation, supra note 202, at 283.

210. Coffee, Rescuing, supra note 67, at 224.

211. See Stephenson, supra note 54, at 116 (" [G]overnment regulatory agencies (it is often claimed) are better at screening out enforcement actions that are either nonmeritorious or not worth the costs of prosecution."); cf. U.S. SEC, 2006 Performance and Accountability Report 2 (2006), available at http://www.sec.gov/about/secpar/ secpar2006.pdf (on file with the Columbia Law Review) [hereinafter SEC, 2006 Accountability Report] (reporting that the Commission "had a 10-0 record of trial court victories in fiscal 2006, its first perfect year in memory-a strong indication that the agency is bringing the right cases and getting solid results for investors and for taxpayers"). It has also been suggested that private enforcement may lead to greater innovations in the development of the law. Barton $\mathbf{H}$. Thompson, Jr., The Continuing Innovation of Citizen Enforcement, 2000 U. Ill. L. Rev. 185, 206. But profit-driven private enforcers "naturally look [] for the easy victories." Garth et al., supra note 71, at 377. Therefore, "creativity and innovation in the generation of the lawsuit are unlikely." Id.

212. Cornerstone Research reports that only eleven securities class action trials have occurred in the post-PSL.RA period, four of which settled prior to verdict, as compared to hundreds of class action filings. See Cornerstone Research, Securities Class Action Case Filings 2007: A Year in Review 4, 19 (2008), available at http://securities.stanford.edu/ clearinghouse_research/2007_YIR/20080103-01.pdf (on file with the Columbia Law Review) [hereinafter Cornerstone, 2007 Securities Filings]. 
profit-driven private enforcement of an overbroad law like Rule 10b-5 comes with significant downside risks. Private Rule $10 \mathrm{~b}-5$ enforcement may lead to overdeterrence, frustrate the Commission's ability to engage in discretionary nonenforcement, and complicate efforts to take a cooperative approach to regulation. These risks are unrelated to the agency costs born of the attorney-client relationship or the out-of-pocket measure of damages. Ironically, eradicating agency costs could actually increase the risk of overdeterrence by serving to "recouple" the sanction and the bounty. Improving the damages measure in Rule $10 \mathrm{~b}-5$ class actions so that it better reflects the actual net social harm caused by securities fraud is a laudable goal and ought to be pursued, but it alone is an insufficient answer to the dilemma posed by private Rule $10 \mathrm{~b}-5$ enforcement: Assuming that the sanction remains sufficient to induce private enforcers to bring claims, Rule 10b-5's overbreadth and ambiguity will continue to present the risks identified above.

If the current system of private enforcement is superior to exclusive Commission enforcement, it is because actual or potential budgetary constraints on the Commission would lead to a level of underdeterrence that would impose greater costs than allowing private enforcement (a rationale that does not support allowing copycat Rule 10b-5 class actions), or because the Commission is so inefficient and/or captured that allowing it to exclusively control enforcement would result in greater deviations from optimal deterrence than private enforcement. Whether the current system of private enforcement is in fact superior is difficult if not impossible to determine empirically. It would be immensely challenging to quantify the costs and benefits of the Rule 10b-5 enforcement system as it exists today, ${ }^{213}$ let alone to quantify the costs and benefits of a counterfactual system of exclusive Commission enforcement. Recent comparative empirical research on enforcement intensity, however, might give one pause before charging that private Rule $10 \mathrm{~b}-5$ enforcement is clearly necessary because the SEC is underfunded or undermotivated. This research not only suggests that the SEC enforces securities laws more intensely than financial regulators in other jurisdictions, it also casts doubt on the conclusion of prior studies that private enforcement is more important than public enforcement in promoting financial development. ${ }^{214}$

213. See Jackson, Intensity of Regulation, supra note 202, at 257-63 (describing the difficulties of applying cost-benefit analysis to financial services industry).

214. Compare Rafael La Porta, Florencio Lopez-de-Silanes \& Andrei Shleifer, What Works in Securities Laws?, 61 J. Fin. 1, 27-28 (2006) (asserting that private enforcement is more important), with Coffee, Law and the Market, supra note 7, at 250-53 (summarizing criticisms leveled at the previous article's "breathtakingly overbroad conclusion that public enforcement was relatively unimportant"), and Howell E. Jackson \& Mark J. Roe, Public and Private Enforcement of Securities Laws: Resource-Based Evidence 1-4 (June 3, 2008) (unpublished manuscript, on file with the Columbia Law Review), available at http:// ssrn.com/abstract $=1000086$ (also questioning effectiveness of private enforcement relative to public enforcement). Others have concluded that "for the United States at least, private 
The foregoing analysis is nevertheless relevant to the reform debate. As explained in the next Part, identifying and understanding the downsides and potential upsides of private Rule $10 \mathrm{~b}-5$ enforcement relative to a system of exclusive Commission enforcement broadens the scope of that debate in an important way.

\section{Improving Deterrence By Restructuring the Relationship Between Commission and Private Enforcement}

As explained above, it is possible-though by no means clear-that the risks that attend private Rule $10 \mathrm{~b}-5$ enforcement are more tolerable than the risks that would attend exclusive Commission enforcement. If policymakers were faced with a binary choice between the current Rule 10b-5 enforcement system and exclusive Commission enforcement, this uncertainty might favor maintaining the status quo. But policymakers are not so constrained in how they approach enforcement of the antifraud provisions of the securities laws. Assuming that it is otherwise cost-effective, any incremental reform to the current system that serves to minimize the risks that attend private enforcement, while continuing to guard against the risks that would attend exclusive Commission enforcement, should result in a net improvement to the Rule $10 \mathrm{~b}-5$ enforcement regime and, ultimately, social welfare.

Short of eliminating private enforcement altogether, there are two very different approaches policymakers can take to mitigating the risks that attend private enforcement of an overbroad law. First, policymakers can narrow the scope of private liability-either directly, by altering the substantive liability rule, or indirectly, by altering the procedural law to disfavor the particular types of suits thought most undesirable (the "narrowing approach"). ${ }^{215}$ Second, policymakers can grant the public enforcer some level of control over private litigation, so as to reintroduce the possibility of discretionary nonenforcement and cooperative regulation (the "oversight approach").

Securities class action reform efforts to date have tended to follow the narrowing approach. As explained in Part II.B.1, aspects of the PSLRA, key judicial decisions like Central Bank and Stoneridge, and contemporary proposals to eliminate enterprise liability can all be viewed as seeking to narrow Rule 10b-5's overbreadth.

Little serious attention, however, has been paid to the oversight approach. ${ }^{216}$ This is perhaps unsurprising: Rule $10 \mathrm{~b}-5$ class actions do con-

and public enforcement activities both are important in the control of managerial opportunism." See Karpoff, et al., Legal Penalties, supra note 203, at 4.

215. See supra note 151 .

216. A few scholars have suggested reforms grounded in oversight. Professor Arlen, for example, is working on a proposal that would grant the Commission some limited ability to prevent private litigation against firms that fulfill their policing duties. See Arlen, Public Versus Private, supra note 157, at 47. In addition, Professor Fisch has previously argued the benefits of providing for greater government oversight of small claims class 
tinue to "take[] the form of compensatory proceedings, i.e., traditional tort suits," 217 and requiring an individual who has been harmed to seek the government's approval or consent before being entitled to pursue relief against the wrongdoer is inconsistent with the corrective justice ideals that underpin tort law.

As detailed in Part I, however, the compensatory justification for Rule 10b-5 class actions today "has relatively few informed, non-self-serving defenders," 218 at least in relation to suits alleging aftermarket fraud against nontrading issuers. ${ }^{219}$ Moreover, to the extent there is any residual compensatory function for Rule $10 \mathrm{~b}-5$ class actions, the "Fair Funds" provision of the Sarbanes-Oxley Act of 2002 now permits the Commission to perform that function by expressly authorizing the payment of substantial penalties recovered in administrative proceedings to injured investors. ${ }^{220}$ There is therefore no compelling reason to allow

actions generally. See Fisch, supra note 54, at 198-202; see also id. at 200 (observing in passing that "the obligation to submit a securities fraud complaint to the SEC or an antitrust suit to the Federal Trade Commission prior to filing might be less onerous than legislative restrictions on private rights of action"). Professor Alexander's proposal to shift to a regime of civil penalties under Rule $10 \mathrm{~b}-5$ also contemplates some level of government oversight. See Alexander, Rethinking Damages, supra note 45, at 1517 ("Plaintiffs would also be required to give notice of the action to the SEC, which would have the option to take over the action and, in any event, appear at any settlement hearing."). Professor Bucy has also argued that the qui tam model of the False Claims Act should be expanded to cover the national financial markets because it attracts valuable inside information and "allows for government monitoring and control of private actions and for cooperation between public and private regulators." Bucy, supra note 27 , at 80 ; see also Coffee, Law and the Market, supra note 7, at 304-05 (noting that "it makes sense to place greater reliance on public enforcement" in light of failure of private enforcement to impose penalties on culpable insiders).

217. Frankel, supra note 52, at $\mathbf{5 7 0 .}$

218. Langevoort, Capping Damages, supra note 40 , at 651.

219. Cases involving insider trading are different. "Diversification provides complete protection only in a simple securities fraud case. In a case of fraud with insider trading, the perpetrators extract some of the gain that would otherwise go to innocent traders." Booth, supra note 95 , at 13 . Suits against trading issuers, such as those involving allegations of fraud in an IPO, also result in more meaningful wealth transfers. But the securities laws provide express private remedies to cover the most common of these situations. See 15 U.S.C. $\$ 77 \mathrm{k}$ (2006) (providing cause of action for material misstatements or omissions in registration statements); id. $\$ 771$ (a) (2) (establishing similar cause of action with respect to prospectuses and other communications in conjunction with an offering); id. $\$ 78 \mathrm{p}$ (b) (permitting issuers to recover profits earned by beneficial owners, directors, and officers from purchases or sales made on basis of inside information); id. $\$ 78 \mathrm{t}-1$ (creating liability to contemporaneous traders for insider trading).

220. "Prior to the Sarbanes-Oxley Act, when the Commission received payment of a penalty, it was required to transmit such money to the U.S. Treasury. Section 308(c) changed the law to permit penalty sums collected to be added to disgorgement funds in certain circumstances." SEC, SOX Report, supra note 65 , at 5; see 15 U.S.C. $\$ 7246$ (codifying "Fair Funds" change); 17 C.F.R. $\$ \S 201.1100-201.1106$ (2008) (implementing corresponding rules). The Commission recently reported that it has returned over $\$ 1$ billion to investors through Fair Funds since 2005, and that several additional large 
the outdated form of private Rule $10 \mathrm{~b}-5$ litigation to preclude consideration of oversight reforms going forward.

In substance, the modern Rule $10 \mathrm{~b}-5$ class action is more like the express "private attorney general" statutes that Congress has adopted than a traditional tort suit. Notably, those statutes typically do provide for some level of government control over private litigation. The False Claims Act, for example, expressly authorizes the Department of Justice to intervene and to move to dismiss a qui tam action brought under that statute, regardless of whether the suit has merit, and notwithstanding that the government itself has not pursued relief against the defendant. ${ }^{221}$ The government's motion will be sustained so long as dismissal has a rational relationship to a valid government purpose that is not otherwise "fraudulent, arbitrary, capricious, or illegal."222 The False Claims Act also flatly precludes qui tam actions predicated on fraud that is already being pursued by the government, ${ }^{223}$ or which has already been publicly disclosed (unless the qui tam plaintiff is the "original source" of the information), ${ }^{224}$ thus ensuring that private enforcement truly supplementsrather than merely duplicates-public enforcement efforts. Even citizen suits brought under the environmental laws (which, as noted above, may do better at achieving deterrence than Rule $10 \mathrm{~b}-5$ class actions ${ }^{225}$ ) are precluded if the government has already taken remedial action. ${ }^{226}$ Plaintiffs under both regimes must notify the responsible government agency of their intent to sue prior to filing, so as to allow that agency to first address the matter itself. ${ }^{227}$

In addition, an analogue to the oversight approach may be found in derivative litigation. Just as allowing unrestricted private enforcement of Rule 10b-5 can interfere with the Commission's ability to effectively set enforcement policy in order to protect the capital markets, allowing un-

disbursements are pending and will be announced shortly. SEC Investor Protection Hearing Statement, supra note 156, at 11; see also SEC, 2006 Accountability Report, supra note 211, at 23 ("In FY 2007, the SEC expects to distribute a significant amount of the approximately $\$ 3.3$ billion dollars collected for distribution in . . 26 mutual fund cases.").

221. See 31 U.S.C. $§ 3730$ (c) (2) (A) (2000).

222. Sequoia Orange Co. v. Baird-Neece Packing Corp., 151 F.3d 1139, 1145 (9th Cir. 1998); accord Ridenour v. Kaiser-Hill Co., LLC, 397 F.3d 925, 936 (10th Cir. 2005); cf. Swift v. United States, 318 F.3d 250, 252-53 (D.C. Cir. 2003) (holding that government has unfettered discretion to dismiss qui tam suits).

223. See 31 U.S.C. $\S 3730(\mathrm{e})(3)$.

224. See id. $\$ 3730($ e) (4); see also Rockwell Int'l Corp. v. United States, 127 S. Ct. $1397,1407-09$ (2007) (interpreting "original source" requirement).

225. See supra notes 164-166 and accompanying text.

226. Zinn, supra note 57, at 154-55. Controversy remains, however, regarding the forms of agency action that suffice to preempt citizen suits, and as to how diligently the government must be pursuing such action. See id.

227. See 31 U.S.C. $\$ 3730$ (b) (2); Zinn, supra note 57, at 152. Even "Title VII [of the Civil Rights Act] prioritizes public over private enforcement in the sense of conditioning the latter on the issuance by the EEOC of a right-to-sue letter." Nagareda, Class Actions, supra note 186, at 624 . 
restricted derivative litigation can interfere with a board of directors' ability to effectively manage the affairs of a corporation. The law does not grant the derivative plaintiff carte blanche to sue to vindicate the corporation's interests. To the contrary, like the government under the False Claims Act, the board of directors is generally entitled by law to notice of the derivative plaintiff's intent to sue, an opportunity to pursue or settle the matter itself, and significant authority to block the litigation, even if it chooses to take no action; moreover, an independent board's judgment must be respected by the courts if it comports with the deferential business judgment rule. ${ }^{228}$ These requirements prevent the derivative plaintiff from usurping the discretion of the board, and from pursuing cases that are in the derivative plaintiff's-but not the corporation's-best interests. ${ }^{229}$ By the same token, they allow derivative litigation to proceed when it is demonstrated that the board lacks independence or has acted without a rational basis. ${ }^{230}$

That no comparable restrictions attend private Rule 10b-5 litigation is a byproduct of the private right's compensatory origins. The modern securities class action has so far departed from those common law origins, however, that the concerns with overdeterrence set forth above suggest that policymakers ought to broaden the securities litigation debate and at least consider the benefits of an oversight approach to reform. ${ }^{231}$ As explained below, an oversight approach offers some significant advantages over the narrowing approach as a mechanism for improving the deterrence function of Rule $10 \mathrm{~b}-5$ litigation, and is worthy of further exploration.

228. For a more thorough discussion of these requirements, see ALI, Principles of Corporate Governance: Analysis and Recommendations $\$ \S 7.01-7.17$ (1994) [hereinafter ALI, Corporate Governance]; 2 David A. Drexler et al., Delaware Corporation Law and Practice $\$ \S 42.01-42.05$ (2007). The prerequisites for maintenance of a derivative suit are dictated by state law, not the federal securities laws. Kamen v. Kemper Fin. Servs., 500 U.S. 90, 108-09 (1991); Burks v. Lasker, 441 U.S. 471, 477-80 (1979).

229. Aronson v. Lewis, 473 A.2d 805, 812 (Del. 1984) (noting that the "demand requirement is a recognition of the fundamental precept that directors manage the business and affairs of corporations"), overruled on other grounds by Brehm v. Eisner, 746 A.2d 244 (Del. 2000).

230. ALI, Corporate Governance, supra note $228, \S 7.03$.

231. So, too, should European policymakers, as they consider adoption of private enforcement mechanisms to strengthen investor protections abroad. For a discussion of European developments, see Richard Nagareda, Aggregate Litigation Across the Alantic and the Future of American Exceptionalism, 62 Vand. L. Rev. (forthcoming Jan. 2009), available at $\mathrm{http}: / /$ ssrn.com/abstract=1114858 (analyzing transatlantic civil litigation on aggregate basis, focusing on class actions); Stefano M. Grace, Note, Strengthening Investor Confidence in Europe: U.S.Style Securities Class Actions and the Acquis Communautaire, 15 J. Transnat'l L. \& Pol'y 281 (2006) (discussing emergence of L.S.-style securities class actions and impact of this phenomenon on European investment community). 


\section{A. The Narrowing Approach}

The narrowing approach places policymaking control in the hands of Congress and, ultimately, the courts. Both institutions are constrained to exercise such authority relatively rigidly, by (respectively) enacting and interpreting static rules defining the scope of private Rule $10 \mathrm{~b}-5$ liability, even as the dynamics of the marketplace continue to change over time. ${ }^{232}$ The upshot is that a narrowing approach risks replacing overinclusion with underinclusion. Indeed, it risks creating precisely the "loopholes" overbroad laws seek to avoid. ${ }^{233}$ Eliminating enterprise liability in private Rule 10b-5 litigation, for example, could ensure that corporations do not excessively invest in precautions to protect against fraud by their agents, but it might also lead to an inadequate investment in precautions. "As with [enterprise] liability, secondary liability may have an important role to play in deterring securities fraud"-if properly controlled rather than eliminated entirely. ${ }^{234}$ Similarly, the PSLRA's "heavy pleading requirements . . . [and] excessively deep harbor for forward-looking disclosure ... raise the risk that too many meritorious claims will . . . be barred." 235

While theoretically the Commission could pursue cases where sanction is warranted but private relief precluded, the very resource limitations that are said to justify private enforcement in the first instance may render this option illusory. ${ }^{236}$ Inefficiency or capture might also prevent the Commission from policing in that gap. Moreover, despite legislative and judicial attempts to narrow the private right of action under Rule $10 \mathrm{~b}-5$, substantial overbreadth does and will remain. Enterprise liability is but one example. The bipartisan Committee on Capital Markets Regulation recently advised that "there needs to be greater clarity to private litigation under Rule 10b-5." 237 It recommended that the SEC provide more guidance on such things as materiality, scienter, and reliance, to help ensure that the U.S. capital markets stay competitive in the global economy. ${ }^{238}$ The narrowing approach is thus at best an incomplete

232. As Justice Scalia recently observed, courts "must apply judgment" when deciding cases- "[b]ut judgment is not discretion." Tellabs, Inc. v. Makor Issues \& Rights Ltd., 127 S. Ct. 2499, 2515 (2007) (Scalia, J., concurring in judgment). See generally Kenneth M. Rosen, "Who Killed Katie Couric?" And Other Tales From The World of Executive Compensation Reform, 76 Fordham L. Rev. 2907 (2008) (discussing advantages of SEC rulemaking vis-à-vis congressional legislation).

233. Landes \& Posner, supra note 118 , at 38 ("The more particularly the legislature tried to describe the forbidden conduct, the more loopholes it would open up.").

234. Pritchard, Markets as Monitors, supra note 41, at 996.

235. Langevoort, Capping Damages, supra note 40 , at 640-41.

236. The PSLRA expressly applies only to private securities litigation, 15 U.S.C. $\$ 78 \mathrm{u}-$ 4 (2006), and thus does not limit the Commission's authority to bring enforcement actions under Rule 10b-5. Moreover, Congress has made clear that Central Bank does not limit the Commission's ability to bring civil aiding and abetting claims. See 15 U.S.C. $§ 78 t(e)$; S. Rep. No. 104-98, at 19 (1995), reprinted in 1995 U.S.C.C.A.N. 679, 698.

237. Zingales et al., supra note 96 , at xii.

238. Id. at $80-82$. 
guard against the risk of overdeterrence, and where it does guard against that risk, it introduces a nontrivial risk of underdeterrence. ${ }^{239}$

\section{B. The Oversight Approach}

The oversight approach, by contrast, places policymaking control back in the hands of public enforcers, thus reintroducing the possibility of discretionary nonenforcement and cooperative regulation. As discussed more fully in this subsection, it can therefore avoid the conundrum between over- and under-deterrence presented by the narrowing approach, assuming that the oversight regime is properly structured so as to guard against inefficiency and capture on the part of the public enforcer.

What might oversight reform look like in the context of private Rule $10 \mathrm{~b}-5$ enforcement? The putative private enforcer (i.e., the class representative and its counsel) could be required, prior to filing a Rule $10 \mathrm{~b}-5$ class action complaint in federal court, to submit it to the Commission for review. Based on such review, the Commission could be required to either grant or deny the right to file. It might deny the right based either on a determination to pursue the matter itself, or because it does not view the litigation as necessary or appropriate in the public interest, taking into account the protection of investors, efficiency, competition, and capital formation. Conversely, a decision to grant the right to file might be based on a determination that allowing suit is consistent with the public interest, taking into account the same considerations. ${ }^{240}$

Authorizing the Commission to prescreen Rule $10 \mathrm{~b}-5$ class action complaints in this manner would return to it full control over, and thus ultimate responsibility for, Rule $10 \mathrm{~b}-5$ enforcement policy. ${ }^{241}$ By controlling which class actions are filed-and, importantly, against whom-the

239. Judicial retrenchment of modern antitrust doctrine can similarly be viewed as an example of a narrowing approach to reform. Kovacic, Private Monitoring, supra note 132, at 782-83 (discussing court rulings imposing restrictive standing and injury tests for private plaintiffs in antitrust cases and observing that "[r]elying on judicial interpretation to limit private enforcement of overly broad statutory commands presents risks," as "[c]ourts might try to curb private enforcement through distorted constructions that forestall the prosecution of socially counterproductive private claims but also impede the pursuit of valid private cases").

240. Oversight reform could target a more limited category of Rule $10 \mathrm{~b}-5$ cases. For example, Professor Arlen has suggested that the SEC be given some level of oversight authority over that subset of securities fraud cases targeting a corporation based on principles of respondeat superior liability. She would not limit private suits against individual defendants. Arlen, Public Versus Private, supra note 157, at 20. The procedural details of oversight reform could also vary widely regarding such things as, for example, the timing of agency intervention and the scope and nature of judicial review. See, e.g., infra note 255. The purpose of the example provided here is to demonstrate the advantages of oversight as a conceptual approach to reform, not to provide the details of an optimal oversight reform package.

241. Technically this type of proposal could be implemented through use of the Commission's exemptive authority under section 36 of the 1934 Act: 
Commission could once again engage in discretionary nonenforcement, as well as make full use of its nuanced and flexible remedies, allowing private enforcers to pursue out-of-pocket class damages only when it believes such relief is appropriate. ${ }^{242}$ This would ensure that private enforcement efforts truly "supplement" the Commission's efforts, rather than duplicate or frustrate them. It might also justify reconsideration of the most onerous provisions of the PSLRA, and perhaps even lead to the legislative repeal or modification of Central Bank. Neither the PSLRA nor Central Bank limits the Commission's discretion to pursue enforcement actions. ${ }^{243}$ If the Commission is able to apply that discretion to screen Rule $10 \mathrm{~b}-5$ class complaints, there would be less reason to continue imposing those limitations in private litigation.

An oversight approach would also allow for a more cooperative style of regulation. For example, if particular conduct falls within a gray area of Rule 10-5 liability, the Commission could preclude class action claims based on such conduct. If, after a dialogue with industry participants, it determines that such conduct ought to be held a violation, it could issue a clarifying release and permit class action claims based on such conduct only on a going-forward basis. ${ }^{244}$ In addition, such a regime might en-

[T] he Commission, by rule, regulation, or order, may conditionally or unconditionally exempt any person, security, or transaction, or any class or classes of persons, securities, or transactions, from any provision or provisions of this chapter or of any rule or regulation thereunder, to the extent that such exemption is necessary or appropriate in the public interest, and is consistent with the protection of investors.

15 U.S.C. $\$ 78 \mathrm{~mm}(\mathrm{a})(1)$ (2006). For political reasons, however, it would likely require congressional action.

242. If more than one defendant were named in a complaint, a decision to grant the right to file would need not extend to all defendants; rather, the Commission could specify the defendants against whom class relief may be pursued, and explain why relief against the other named defendants is denied. For example, the Commission could choose to grant the right to file against individual wrongdoers, but not against the corporate defendant, or vice versa; or it could grant the right to file against the corporate defendant but not the auditor. In such cases, the Commission could choose to itself pursue some form of relief (monetary or otherwise) against the defendant(s) it has spared from class litigation.

243. See supra note 236 .

244. See Grundfest, Rights of Action, supra note 31, at 1015. As Professor Grundfest explains, "there can be substantial good faith confusion over the question whether disclosures are adequate to comply with complex rules that have received little Commission interpretation and with which practitioners have little experience." Id. He suggests that:

The Commission could therefore determine that it is imprudent to subject registrants to the risk of private party liability if there is still room for confusion over novel and complex disclosure requirements, and the Commission could use its disimplication authority to shelter issuers from Rule $10 \mathrm{~b}-5$ private liability until it determines that the standards for compliance are sufficiently clear to support such exposure.

Id.; see also Cox \& Greene, supra note 158, at 248 (observing that "predictability in enforcement is less of a concern when the object of enforcement action is merely to 
courage corporations to work with the Commission to improve internal controls and to promptly disclose failures in those controls when they occur by eliminating the constant threat of class action litigation that may deter such cooperation today. ${ }^{245}$ It might also strengthen momentum for the adoption of a more "principles-based" approach to regulation. ${ }^{246}$

An oversight approach to securities litigation reform might also beneficially affect the manner in which corporations defend against Commission action. Under the current system, the Commission enjoys considerable power to coerce settlement. Corporations may settle with the Commission for fear of the res judicata effect of an adjudicated loss in a subsequent Rule $10 \mathrm{~b}-5$ class action, ${ }^{247}$ and they may do so early and at a substantial premium in order to avoid being asked to produce documents (including privileged documents) that may be discoverable in subsequent class action litigation. ${ }^{248}$ If a Commission enforcement action precluded subsequent class action litigation, however, corporations would have greater incentive to fight back when they believe the Commission is overreaching, and to settle fully and finally when actual wrongs are discovered. ${ }^{249}$

Reform based on enhanced Commission oversight of private class actions would also go a long way toward rehabilitating the public image of the securities fraud class action, thus enhancing its strength as a deterrent. Today, it is too easy for officers to discount the importance of fraud

require that challenged conduct cease; concerns for predictability are heightened if the regulator seeks not only cessation of the conduct but to impose a fine or other sanction on the respondent").

245. See supra note 157 .

246. See supra note 158 .

247. See Coffee, Rescuing, supra note 67, at 225 n.21 (citing Parklane Hosiery Co. v. Shore, 439 U.S. 322 (1979)); see also Erichson, supra note 174, at 29 (describing "issue preclusion risk" as "one of the strategic incentives at play for the defendant in settlement negotiations" with the government).

248. See supra note 158; see also Sturc \& Dickey, supra note 36, § 15:3.1 ("[I]n practice the Staff [of the SEC] has consistently asked companies to produce their privileged materials."). The practice of federal regulators to require attorney-client privilege waivers as a condition for leniency in corporate fraud investigations has been subject to significant criticism recently, by both lawmakers and industry groups. See Evan Perez, U.S. Is Revising Rules on White-Collar Crime, Wall St. J., July 10, 2008, at A12; Pedro Ruz Gutierrez, AG Mukasey Hints at Revision of McNulty Memo, Spars with Senators at Hearing, Legal Times, July 10, 2008, at http://www.law.com/jsp/article.jsp?id=12024228 64034 (on file with the Columbia Law Reivew). The threat of criminal prosecution raises a host of additional issues which are beyond the scope of this Article. See, e.g., Scott A. Resnik \& Keir N. Dougall, The Rise Of Deferred Prosecution Agreements, N.Y. L.J., Dec. 18,2006 , at 1 ("The stigma of indictment alone is likely to cause the flight of clients, precipitous loss of business, plummeting stock prices, and onerous reporting obligations.").

249. It has been suggested that private enforcement "is potentially 'fairer' because the private plaintiff does not have the same built-in advantage as the public prosecutor or regulatory agency, to whom courts have a tendency to defer." Coffee, Rescuing, supra note 67, at 227. However, much of the Commission's "unfair" advantage is the product of private enforcement. 
allegations made in the context of class litigation, because the plaintiffs' class action bar has been so demonized in the popular media. ${ }^{250}$ If securities class actions bore the imprimatur of the Commission, however, it would be much more difficult for officers to dismiss them as mere nuisance filings. ${ }^{251}$

While an oversight approach could significantly mitigate the risks that attend private enforcement, it admittedly raises some of the same concerns that are associated with exclusive Commission enforcement-in particular, the possibility that inadequate enforcement resources, bureaucratic inefficiency, and/or regulatory capture might lead to greater deviations from optimal deterrence than unrestricted private enforcement. As noted above, however, the narrowing approach raises these concerns as well, at least with respect to the conduct that approach immunizes from private enforcement. ${ }^{252}$ Moreover, safeguards could be built into an oversight reform package to minimize these risks.

For example, the prospect of the Commission commandeering a Rule $10 \mathrm{~b}-5$ class action might dissuade some private enforcers from participating in the system, thus reducing the amount of private resources available to supplement the Commission's enforcement efforts (although it is unlikely that private enforcers would disappear entirely, given the possibility of substantial recovery if the right to file is granted). This disincentive could be offset, however, by granting a putative private enforcer the right to reasonable recompense if the Commission were to choose to take over the matter. ${ }^{253}$

250. See Gilles \& Friedman, supra note 70, at 129-31 (discussing public perception that class actions are device invented by plaintiff's bar to enrich itself at expense of class members).

251. See Pritchard, Markets as Monitors, supra note 41, at 1016 (observing that "credibility of the enforcer matters" in a deterrence regime). The reform could also be designed to temper the risk of collusive settlements by requiring that the Commission be notified of and comment on the adequacy and fairness of Rule 10b-5 class action settlements. The Class Action Fairness Act of 2005 contains a comparable provision, requiring in diversity class actions that notification of any proposed settlement be given to an appropriate government official prior to its approval. 28 U.S.C.S. $\$ 1715$ (2008). That provision "is intended to combat the 'clientless litigation' problem by adding a layer of independent oversight to prohibit inequitable settlements," as well as to afford the government an opportunity to take action if the settlement is "inconsistent with applicable regulatory policies." S. Rep. No. 109-14, at 34 (2005), reprinted in 2005 U.S.C.C.A.N. 3, 32-33. With a similar objective, the Federal Trade Commission has urged the adoption of an amendment to Federal Rule of Civil Procedure 23 that would require plaintiffs to notify government agencies involved in related actions or investigations of the pendency of a class action lawsuit. See Letter from Timothy Muris, Chairman, Fed. Trade Comm'n, to Peter McCabe, Sec'y, Comm. on Rules of Practice and Procedure of the Judicial Conference of the U.S. 1 (Feb. 15, 2002), available at http://www.ftc.gov/os/2002/02/ rule23letter.pdf (on file with the Columbia Law Review).

252. See supra text accompanying notes 236-239.

253. Cf. Jonathan R. Macey \& Geoffrey P. Miller, The Plaintiffs' Attorney's Role in Class Action and Derivative Litigation: Economic Analysis and Recommendations for Reform, 58 U. Chi. L. Rev. 1, 115 (1991) (opining that similar compensation system for 
Oversight reform could similarly be designed to guard against the risks of capture and regulatory inertia. To guide and cabin its discretion, the Commission could be required to promulgate factors for determining when class action litigation is necessary or appropriate in the public interest. Any such factors should not be so rigid as to eliminate the very discretion oversight reform is designed to preserve, of course. The factors the Commission currently considers in deciding whether to impose penalties on a corporation provide a good template for class action complaints against corporate defendants. ${ }^{254}$ Moreover, to further protect against arbitrary or biased decisions, the Commission could be required to articulate in writing its basis for denying or granting the right to file in a particular case. ${ }^{255}$ It could also be required to prepare a report for Congress periodically detailing its decisions granting and denying the right to file, and tracking the status of its Rule $10 \mathrm{~b}-5$ enforcement efforts as well as the Rule $10 \mathrm{~b}-5$ class actions which it has permitted to proceed. Those reports could allow for comparison between the penalties, disgorgement, and other relief imposed by the Commission and the money recovered by private enforcers. ${ }^{256}$ This transparency and accountability might reduce the likelihood that the Commission would too often deny the right to file, and too often decline to pursue matters itself (or to pursue them vigorously enough). It could also protect against the perhaps more likely possibility (discussed in greater detail below) that the Commission would be too generous in allowing class actions to proceed.

\section{Potential Challenges to an Oversight Regime}

An oversight approach to securities litigation reform, such as the one sketched out above, begs some obvious questions-important questions that deserve the attention of commentators and policymakers. A few of these are identified, and addressed, in this Subpart. The purpose of this

"first movers" would be adequate to ensure participation under an auction approach to securities fraud claims). While the risk of an outright Commission veto might also dampen private incentives to bring suit, presumably such a veto would be reserved for particularly weak cases. If so, the disincentive would be laudable and reimbursement inappropriate.

254. See supra note 150 and accompanying text.

255. In qui tam suits under the False Claims Act, the government is not required to take an affirmative position on the suit at the outset, although it can intervene and move to dismiss at any point. This creates structural incentives for the government to sit back and allow the suits to proceed, without truly exercising any oversight function. Matthew, supra note 159, at 297-98; see also Kovacic, Whistleblower, supra note 188, at 1848-49 (arguing for more vigorous screening of qui tam suits by the Department of Justice). The approach suggested here avoids that problem.

256. "Although the Commission carefully documents its own enforcement activities for the public record, it [currently] makes no effort to analyze its enforcement program in the larger context of a litigation system that also permits private enforcement of the securities laws." Grundfest, Rights of Action, supra note 31, at $971 \mathrm{n} .24$. If the putative private enforcer were granted the right to file, it could be required to provide copies of all subsequent pleadings in the litigation to the Commission, so that the Commission could stay abreast of developments (and, if so inclined, weigh in as an amicus). 
discussion is not to provide an exhaustive analysis of the pros and cons of oversight reform, since the precise questions (and answers) would depend on the contours of any particular reform proposal. Rather, the goal of this Subpart-and, indeed, the proposal as a whole-is to begin a dialogue among academics, market participants, and ultimately policymakers regarding the relative advantages and disadvantages of using Commission oversight as an additional tool to enhance the efficiency of our capital markets by mitigating the risks inherent in private Rule 10b-5 litigation. ${ }^{257}$

Why maintain the Rule 10b-5 class action at all, dressed as it is in its outdated compensationalist clothing-instead, why not abolish it entirely and replace it with a pure bounty system akin to the False Claims Act?

The answer to this question is threefold. First and most practically, maintaining the Rule $10 \mathrm{~b}-5$ class action, while subjecting it to Commission screening, is less extreme and thus should stand a better chance of actual adoption or, at least, serious consideration. Abolishing private securities class actions could well be viewed as politically infeasible, and thus an unhelpful beginning to a serious debate on securities litigation reform. Expanded Commission oversight, by contrast, is-or ought to be-a real possibility that should garner both adherents and detractors, thus ensuring a meaningful dialogue. Second, adopting a pure bounty system would raise difficult constitutional questions on standing that an oversight-based approach avoids. ${ }^{258}$ Third, while Rule $10 \mathrm{~b}-5$ class actions do not serve a compensatory function that is meaningful enough to justify unconstrained private enforcement, investor compensation could be a residual benefit. Some class members, at least, will have sustained actual, net losses as a result of securities fraud and, in any event, it makes sense to return the money recovered to the pockets of investors (rather than to, for instance, the U.S. Treasury). Securities fraud increases the cost of raising capital in part by discouraging participation in the capital markets; if investors use their damage awards to reinvest in securities, the increased demand would work to offset that harm. Moreover, there may be a benefit to making investors feel as if they have a means of redress, even if it is not a truly meaningful one in the economic sense-it may serve to increase investor confidence and willingness to

257. See supra note 240 (describing some options for implementing oversight-style reform).

258. It is unclear whether a pure bounty-hunter plaintiff would satisfy Article III's "injury in fact" requirement, as interpreted by the Supreme Court in Lujan v. Defenders of Wildlife, 504 U.S. 55. 560-61 (1992) (holding, inter alia, that plaintiff must have suffered "invasion of a legally protected interest which is . . . concrete and particularized" to have standing). For a more detailed discussion of this question, see Alexander, Rethinking Damages, supra note 45, at 1517-19 (explaining that issues of injury and redressability remain problematic in context of citizen suits); Fisch, supra note 54, at 186-94 (arguing that constitutional limits on standing pose an issue in qui tam litigation, even if prudential limits do not). 
participate in the capital markets which, again, would work to offset the harm caused by securities fraud.

If it is true that some class members, at least, will have sustained actual, net losses as a result of securities fraud, isn't it unfair to allow the Commission to deny them their right to relief?

The short answer is that the proposal outlined above does not authorize the Commission to deny any individual of any substantive right; it merely authorizes the Commission to deny an individual the opportunity to represent a class under Federal Rule of Civil Procedure 23. ${ }^{259}$ Individual Rule 10b-5 suits would remain available to those who have been wronged under the Act. To be sure, investors with small stakes may find it uneconomical to bring such a suit, whereas large investors may not. Although this may seem unfair, in reality most "mom and pop" investors own mutual fund shares rather than direct equity stakes in corporations and usually must rely on their mutual fund managers to sue on their behalf. ${ }^{260}$ Other small investors are likely to trade infrequently, which means that they are the most burdened by Rule $10 \mathrm{~b}-5$ class actions. This is because, under the transacting-plaintiff requirement of Blue Chip Stamps, they will more often be on the paying end of a Rule $10 \mathrm{~b}-5$ class action than a member of the class. ${ }^{261}$ Moreover, in cases involving serious allegations of fraud, one would expect the Commission to deny the right to file only if it has determined to pursue the matter itself. In such a case, investors may very well receive compensation through a Fair Funds distribution. ${ }^{262}$

If individual Rule 10b-5 suits would remain available without restriction, isn't it possible that large institutional investors would bring such suits and upset the deterrence calculus in the same way class actions do now?

The answer is that this is possible, ${ }^{263}$ particularly given the growing trend of institutional investor "opt outs" in Rule $10 \mathrm{~b}-5$ class

259. As explained in Part I.A, it was the emergence of the modern class device along with the courts' adoption of the fraud-on-the-market presumption of reliance that transformed securities fraud lawsuits from primarily compensation-oriented actions to deterrence-oriented ones.

260. See Inv. Co. Inst., 2008 Investment Company Fact Book 8 (48th ed. 2008), available at http://www.icifactbook.org/pdf/2008_factbook.pdf (on file with the Columbia Law Review) (reporting that "between 2003 through 2007, households purchased, on net, a total of $\$ 2.2$ trillion in mutual funds . . . while they sold nearly $\$ 3$ trillion of directly held stock").

261. 421 U.S. 723 (1975) (denying standing under Rule $10 \mathrm{~b}-5$ to investors who neither purchased nor sold shares, but instead refrained from transacting, in reliance on misstatements or omissions).

262. See supra note 220 (describing Commission's ability to compensate those injured by fraud).

263. See Alexander, Rethinking Damages, supra note 45, 1524-25 (noting that "the existence of large-stakes claimants could reintroduce the problems of excessive damages even if class actions were prohibited" and that "[r]etaining an individual right to compensatory damages would thus throw the deterrence calculation underlying the statute out of kilter"). 
actions. $^{264}$ It remains true, however, that most institutional investors do not bring individual Rule $10 \mathrm{~b}-5$ actions today, nor do they participate in class action litigation as lead plaintiffs or, in many cases, even make claims on class settlement funds. ${ }^{265}$ Moreover, as noted in Part II.B.2, institutional investors' interests are more likely to align naturally with the public's interest in achieving optimal deterrence than unmonitored plaintiffs' lawyers, so institutional investor suits present less cause for concern than class actions. That said, if this were perceived as a significant risk, the scope of the Commission's screening authority could be defined as extending to all representational actions on behalf of a certain number of investors, and institutional investors could be counted by reference to their beneficial owners.

The Commission has always shown an affinity for private enforcement; won't it simply use its new authority to allow all class actions to proceed?

It is possible that the Commission would simply rubber stamp all class action complaints that cross its proverbial desk, rendering the reform proposal futile. There are good reasons to believe, however, that this would not occur. To be sure, the Commission has historically supported the plaintiffs' bar in its amicus role, and has not used its rulemaking authority to rein in private suits. ${ }^{266}$ But the structural changes proposed here would fundamentally alter the Commission's incentives. Under the current regime, if the Commission advocates a narrow reading of Rule $10 \mathrm{~b}-5$ or Section 10 (b) as an amicus in a private suit, it risks undermining its own authority to bring enforcement actions under those provisions in the future. Moreover, the SEC presently has an interest in retaining a strong implied private right of action to hedge against the risk that future budgetary cutbacks will cripple its own enforcement efforts. The Commission also generally wants to avoid the appearance of being "soft" on corporate fraud.

Under the oversight regime proposed, these incentives to side with the plaintiffs' bar would be minimized or disappear altogether. The Commission would not need to risk undermining it own authority in order to veto a class action complaint; instead it could base that decision on discretionary, fact-specific criteria demonstrating that the particular suit is not in the public interest. Moreover, the Commission could allow a

264. For a detailed discussion of this trend and its implications, see John C. Coffee, Accountability and Competition in Securities Class Actions: Why "Exit" Works Better than "Voice" (Columbia Univ. Sch. of Law Center for Law \& Econ. Studies, Working Paper No. 329,2008 ), available at http://ssrn.com/abstract $=1113845$ (on file with the Columbia Law Review).

265. See generally James D. Cox \& Randall S. Thomas, Letting Billions Slip Through Your Fingers: Empirical Evidence and Legal Implications of the Failure of Financial Institutions to Participate in Securities Class Action Settlements, 58 Stan. L. Rev. 411 (2005) (exploring institutional investors' frequent failure to submit claims in securities class actions).

266. See Pritchard, Political Economy, supra note 108, at 32-33 (noting, inter alia, SEC's consistent support for the fraud-on-the-market presumption). 
higher percentage of class actions to proceed if and when a budgetary cutback compromises its enforcement capability; the threat of such a cutback need not distort the Commission's decisionmaking in times of ample enforcement resources. Nor should vetoing a class action complaint necessarily be viewed as inconsistent with a tough stance on corporate fraud; if a colorable case has been made for a violation, the Commission could and presumably would pursue the matter itself, at the very least against the officers who perpetrated the fraud if enterprise liability is deemed inappropriate. It should also be stressed that under the proposed regime, the Commission would be clearly responsible for securities fraud deterrence in a way it is not today; if it chooses to allow all class actions to proceed, and the public perceives this as leading to overdeterrence and attendant social losses, the Commission could be called to account before Congress and made to change its behavior. ${ }^{267}$

\section{Is this proposal otherwise cost-effective?}

This question can and should be studied in greater detail. Compensating putative private enforcers for their efforts in the event the Commission takes over the action would require the expenditure of real resources. Moreover, requiring the Commission to screen and monitor the universe of Rule $10 \mathrm{~b}-5$ class actions is obviously not costless. But the total number of Rule $10 \mathrm{~b}-5$ class actions filed in any given year is not inordinately high when considered on a per occurrence basis (that is, after complaints making similar allegations against the same defendants are consolidated for pretrial proceedings by the Judicial Panel on Multidistrict Litigation). ${ }^{268}$ The added costs to the Commission in this regard must be offset by the improved deterrence and savings to the judiciary expected to result from the implementation of such a proposal. Even Rule 10b-5 class actions that are destined to be dismissed for pleading defects under the PSLRA must first go through a time consuming lead plaintiff battle, and "copycat" class actions often are not amenable to dismissal at the pleadings stage-even if it appears that the damages claimed will, at the end of the day, be fully offset by a Fair Funds distribution. ${ }^{269}$ The oversight proposal outlined above would ensure that fewer

267. Moreover, as noted above, a requirement that the Commission express in writing its reasons for granting the right to file in a particular case and to report to Congress should temper the risk of unprincipled decisionmaking. See Rosen, supra note 232, at 2938-39 (discussing benefits of congressional oversight of SEC action).

268. Cornerstone Research places the number of filings at 166 in 2007, 116 in 2006, and 194 on average per year from 1997-2006. See Cornerstone Research, 2007 Securities Filings, supra note 212, at 2. In an oversight regime, if multiple complaints were submitted concerning the same allegations against one or more of the same defendants, the Commission might consolidate its consideration of those complaints and issue only a single decision. If the putative private enforcers intended to file in different judicial districts, a decision granting the right to file might specify the single judicial district in which relief can be pursued (thus obviating the need to engage the multidistrict litigation machinery).

269. See supra note 220 and accompanying text (describing Commission's ability to compensate those injured by fraud). 
of these suits ever see the inside of a courtroom, providing much warranted relief to the federal docket.

\section{CONCLUSION}

For the past twenty-five years, policymakers and commentators have struggled to find ways to improve Rule $10 \mathrm{~b}-5$ class actions, without pausing to ask whether the game is worth the candle-is private enforcement of Rule $10 \mathrm{~b}-5$ preferable to monopolistic Commission enforcement? The time to begin answering that question has arrived. The original compensatory justification for private Rule $10 \mathrm{~b}-5$ enforcement has been jettisoned by most knowledgeable observers, and the Fair Funds provision in the Sarbanes-Oxley Act of 2002 today permits the Commission to deliver compensation to investors in any event. If the Rule 10b-5 class action finds warrant, it is as a supplement to the Commission's deterrence efforts.

Classic law and economics scholarship, however, casts considerable doubt on the desirability of utilizing Rule $10 \mathrm{~b}-5$ class actions as an additional deterrent. Rule $10 \mathrm{~b}-5$ class actions threaten to overdeter and they frustrate the Commission's ability to effectively engage in discretionary nonenforcement and cooperative regulation. These risks are inherent to profit-driven private enforcement of an overbroad law like Rule 10b-5, and would persist even if the agency costs borne of the attorney-client relationship were eradicated and the damages measure employed in Rule $10 \mathrm{~b}-5$ class actions reformed. This is not to say that Rule $10 \mathrm{~b}-5$ class actions should therefore be eliminated. It remains possible that exclusive Commission enforcement would result in even more damaging underdeterrence, due to the Commission's budgetary constraints and the risk of bureaucratic inefficiency or regulatory capture. There is simply inadequate empirical evidence to know for sure.

Identifying the relative advantages and disadvantages of private versus exclusive Commission enforcement of Rule $10 \mathrm{~b}-5$ is helpful in its own right, however, even if it is unclear how they balance out. It serves to frame the problems associated with Rule $10 \mathrm{~b}-5$ class actions in a different way-one that suggests a new, and potentially superior, approach to reform that has heretofore received little serious consideration from either academics or policymakers.

Several of the most controversial private securities litigation reforms to date can be viewed as seeking to narrow Rule 10b-5's overbreadth in order to mitigate the risks that naturally attend private enforcement of an overbroad law. This narrowing approach to reform carries significant costs-viz., it risks replacing overinclusion and overdeterrence with underinclusion and underdeterrence. The resource limitations and risks of inefficiency and capture that are thought to justify private enforcement in the first instance may prevent the Commission from adequately policing the gaps created by these types of reforms. 
An oversight approach to reform offers a possible solution to this conundrum. If the Commission were granted the authority to screen, and approve or reject, Rule 10b-5 class action complaints before filing, it would be unnecessary to rigidly narrow the private right of action to protect against overdeterrence. Instead, we might rely on the Commission to offer that protection in the exercise of its expert discretion. This type of reform carries significant additional benefits, and would not necessarily introduce the dangers of exclusive Commission enforcement. To the contrary, it might be designed to preserve adequate incentives for private enforcers to participate in the system, thus ensuring a consistent level of enforcement resources, and it could build in protections against regulatory capture and shirking.

This proposal obviously raises many questions, which are worth exploring. While Commission control over Rule 10b-5 class actions might seem radical, in reality it is the total absence of such control that is peculiar in this context. In cases where Congress has expressly granted private parties the right to enforce the law for profit, rather than to redress a tortlike injury, it has frequently provided for a level of government oversight. That no comparable restrictions attend private Rule $10 \mathrm{~b}-5$ enforcement is an outdated vestige of the implied right's compensatory origins.

Policymakers ought to expand the scope of the contemporary securities litigation reform debate and seriously consider the virtues of an oversight approach to reform. Giving the Commission an enhanced role in monitoring and supervising private Rule $10 \mathrm{~b}-5$ class actions has the potential to mitigate the risks of private enforcement-particularly the concern that the current regime may lead to overdeterrence and inflexibility-while avoiding the concomitant risks of monopolistic public enforcement. 